\title{
A BRADORIID AND BRACHIOPOD DOMINATED SHELLY FAUNA FROM THE FURONGIAN (CAMBRIAN) OF VÄSTERGÖTLAND, SWEDEN
}

TIMOTHY P. TOPPER ${ }^{1}$, CHRISTIAN B. SKOVSTED ${ }^{2}$, DAVID A.T. HARPER ${ }^{1,3}$ AND PER AHLBERG ${ }^{4}$

\begin{abstract}
${ }^{1}$ Geologisk Museum, Statens Naturhistoriske Museum, Øster Voldgade 5-7, DK-1350 København K, Denmark<timothy.topper@snm.ku.dk>; ${ }^{2}$ Department of Palaeozoology, Swedish Museum of Natural History, Box 50007, SE-104 05 Stockholm, Sweden <Christian.Skovsted@nrm.se>; ${ }^{3}$ Department of Earth Sciences, Durham University, Durham DH1 3LE, UK <david.harper@durham.ac.uk>; and ${ }^{4}$ GeoBiosphere Science Centre, Department of Geology, Lund University, Sölvegatan 12, SE-223 62 Lund, Sweden <per.ahlberg@geol.lu.se>
\end{abstract}

ABSTRACT- A small assemblage of shelly fossils, dominated by the brachiopod Treptotreta jucunda and the bradoriid arthropod Mongolitubulus aspermachaera $\mathrm{n}$. $\mathrm{sp}$. is described from a Furongian limestone of Västergötland, south-central Sweden. Mongolitubulus aspermachaera is represented in the assemblage by individual valves and numerous, ornamented spines. Valves and spines share identical ornament and microstructure leaving no doubt that the isolated spines were once attached to the bradoriid valves. Mongolitubulus aspermachaera adds to the increasing list of spinose Cambrian bradoriid arthropods, and a new family Mongolitubulidae $\mathrm{n}$. fam. is erected here to incorporate the genera Mongolitubulus, Tubuterium and Spinospitella. Mongolitubulus aspermachaera represents the youngest member of the new family and supplements the biodiversity of bradoriids in the Furongian, an interval when bradoriid diversity is considered to be very much on the decline. The brachiopod Treptotreta jucunda described predominantly from the 'middle' to 'late' Cambrian of Australia is here documented for the first time from outside Gondwana, 
dramatically extending the biogeographical range of the species. Other elements of the faunal assemblage include typical Baltic Furongian representatives, such as the trilobite Parabolina, the agnostoid Agnostus and the phosphatocopids Hesslandona and Vestrogothia.

\section{INTRODUCTION}

THE CAMBRIAN System of Scandinavia has been extensively studied since the mid nineteenth century (e.g. Dalman, 1827; Boeck, 1838; Angelin, 1851, 1854) and the trilobite dominated provisional Cambrian Series 3 ('middle' Cambrian) through lower Tremadocian Alum Shale Formation has been the focal point of many studies (e.g. Westergård, 1922, 1944, 1946, 1947; Henningsmoen, 1957; Terfelt, 2003; Axheimer and Ahlberg, 2003; Ahlberg et al., 2005, 2009; Terfelt et al., 2008). The plethora of trilobite specimens in the Furongian includes over 100 polymerid trilobite species documented from Scandinavia resulting in a detailed and precise biostratigraphical zonation (see Terfelt et al., 2008, 2011). The organic-rich limestone nodules and lenses of the Alum Shale in southern Sweden have also yielded exquisitely preserved arthropods, predominantly various crustaceans and minute bivalved phosphatocopids (e.g. Müller and Walossek, 1985, 1987, 1988; Walossek, 1993; Maas et al., 2003). Many other elements of the Furongian faunal assemblages of Scandinavia though, such as brachiopods and bradoriids, have been only sporadically recorded and there remains a dearth of information on their respective abundance and diversity.

Bradoriid arthropods are sparsely represented in the Cambrian of Scandinavia, predominantly documented from glacial erratics, presumably of 'early' and 'middle' Cambrian age (Wiman, 1905; Hinz-Schallreuter, 1993). Approximately 13 Cambrian Scandinavian bradoriid genera have been documented (Wiman, 1905; Hinz-Schallreuter, 1993; Streng et al., 2008; Dies Álvarez et al., 2008; Williams et al. 2007), in addition to a 
number of specimens which have been questionably assigned (e.g. Andres, 1969; Ahlberg, 1989; Streng et al., 2008), their exact systematic position awaiting affirmation (see Streng et al., 2008 for review). Little is known of their stratigraphical ranges but all documented species are restricted to 'early' and 'middle' Cambrian (Cambrian series 2 and 3) strata and to date, the Furongian of Scandinavia has been entirely devoid of bradoriid arthropod specimens. A single species of bradoriid, Eremos bryograptorum Moberg and Segerberg, 1906, has been described from Tremadocian strata of Scania, southern Sweden, representing the lone Ordovician bradoriid species from Scandinavia. Bradoriid diversity had significantly waned by the Furongian, a decline postulated to be the result of intervals of marine shelf anoxia (Williams et al., 2011), and consequently documentation of bradoriid specimens from the Furongian is pivotal in our understanding of their diversity and geographical distribution before their extinction in the early Ordovician (Williams et al., 2008).

Spine-shaped phosphatic fossils characterised by various types of ornamentation are common constituents of 'early' to 'middle' Cambrian shelly fossil assemblages (e.g. Missarzhevsky, 1977; Skovsted and Peel, 2001; Skovsted, 2005; Topper et al., 2007; Wrona 2004, 2009; Kouchinsky et al. 2011). The large majority of these spines have been referred to the engimatic taxon Mongolitubulus Missarzhevsky, 1977, their fragmentary nature prompting numerous interpretations as to their biological function and affinity (see Topper et al., 2007 for review). The discovery of spine-bearing valves of Mongolitubulus unispinosa Topper et al., 2007 from the 'lower' Cambrian of Australia provided strong evidence of the affinity of Mongolitubulus spines with bradoriid arthropods, an interpretation first proposed by Melnikova (2000) and Skovsted and Peel (2001). Bradoriid arthropods exhibiting distinct, ornamented spines attached to their valves have now been documented from numerous Cambrian faunal assemblages across the globe, including Greenland (Skovsted, 2005), Australia (Topper et al., 2007), China (Zhang, 2007), Siberia (Kouchinsky et al., 2011) and 
Sweden (herein). A recently documented species of eodiscoid trilobite from South China (Li et al., 2012) however, has compounded the Mongolitubulus puzzle, by exhibiting spines that show a scale-like ornament, reminiscent of individual Mongolitubulus spines. By implication this find shows that morphologically similar ornamented spines may be a result of convergent evolution, potentially arising multiple times within the ecdysozoan clade and that the generic name Mongolitubulus should be used with some caution (Li et al., 2012).

Mongolitubulus aspermachaera $\mathrm{n}$. sp. is represented in the assemblage from Sweden by numerous valves and individual spines (see Figs 4-5) exhibiting identical ornament and microstructure, indicating that the detached spines belong to the bradoriid valves. Bradoriid valves consequently always display an incomplete, fragmentary posterodorsal margin, an indication of the attachment location of the spine (Fig. 4.1). Mongolitubulus aspermachaera adds to the increasing list of spine-bearing bradoriid arthropod species, the vast majority of which are left under open nomenclature at family level due to the uncertainty regarding the morphological significance of possessing a spinose valve. This has prompted the erection of a new family, Mongolitubulidae n. fam., to accommodate distinct, spine-bearing bradoriid arthropods that do not display diagnostic morphological features indicative of other established Bradoriida families. Mongolitubulidae is proposed on the basis of valve morphology, incorporating among other features, position and number of spines present on the bradoriid valve and includes an emended diagnosis of the type genus Mongolitubulus. Despite the fact that no valves have been directly associated with specimens referred to the type species, Mongolitubulus squamifer Missarzhevsky, 1977, this species deserves inclusion in the new family as the spines of this taxon exhibit microstructures identical to those of other species where spines and valves are associated.

The wide spectrum of ornamentation displayed by spines on the exoskeleton of eodiscoid trilobites ( $\mathrm{Li}$ et al., 2012) highlights the problems associated with the taxonomic 
assessment of isolated spines and as such, isolated, ornamented spines should be approached with vigilance and without convincing evidence to support a bradoriid arthropod affinity should be excluded from the family. Here we document a low diversity, but well-preserved faunal assemblage from the Furongian of Scandinavia, dominated by the acrotretid brachiopod Treptotreta jucunda, the first occurrence of the species in Scandinavia, and the spine-bearing bradoriid arthropod $M$. aspermachaera assigned to the newly erected family Mongolitubulidae.

\section{GEOLOGICAL SETTING}

The Alum Shale Formation of Scandinavia consists of dark, organic-rich and finely laminated shales with lenses and beds of dark grey limestones, known as stinkstones (see Nielsen and Schovsbo, 2006). The succession holistically is dominated by trilobites, in particular the taxonomically restricted Furongian assemblages where olenid trilobites and agnostoids constitute the bulk of the fauna (Ahlberg et al. 2005). The thickest and most complete Furongian successions are located in Scania, southernmost Sweden. In other parts of Scandinavia the Furongian alum shales are either tectonized (along the Caledonian Front) and/or interrupted by hiatuses of various magnitudes. The recent revision of the biostratigraphy of the Furongian of Scandinavia links four agnostoid interval zones with 28 zones based on olenids (Terfelt et al., 2008, 2011).

In Västergötland, the Furongian has a maximum thickness of about $11 \mathrm{~m}$ and there are several gaps in the succession (Westergård 1922; Terfelt 2003). The proportion of limestone relative to shale is considerably greater than observed in other regions around Sweden and exposures can be seen in a number of old quarries (Westergård, 1922; Ahlberg and Ahlgren, 1996; Ahlberg, 2003; Ahlberg et al., 2005; Axheimer et al., 2006). Furongian deposits are 
particularly well exposed in areas surrounding the Kinnekulle and Billingen table mountains and notably around the smaller hills in the Falbygden area. The specimens documented herein were retrieved from a locally derived boulder of a whitish to grey limestone (whitish part has a grainstone texture) just north of an old quarry situated approximately $0.7 \mathrm{~km}$ west of Gudhem church and approximately 9 km north-west of the town of Falköping (Fig. 1). Ahlberg and Ahlgren (1996) described Pseudagnostus cf. cyclopyge (Tullberg, 1880) from this limestone boulder. The associated macrofauna includes Parabolina brevispina Westergård, 1922, Olenus truncatus (Brünnich, 1781), and Agnostus (Homagnostus) obesus (Belt, 1867), with the last-mentioned species being numerically dominant. Based on the trilobite fauna, the sample is derived from the Olenus truncatus and Parabolina brevispina zones from the lower Furongian (for the most updated biostratigraphic scheme see Terfelt et al., 2008, 2011). The Cambrian Series 3 succession (Guzhangian Stage) exposed at the Gudhem quarry was first described by Wallerius $(1894,1895,1930)$ and has subsequently been the setting of several trilobite based publications (Axheimer et al., 2006). Furongian strata are not exposed in the Gudhem quarry but have been described from other localities in the western Falbygden area (Westergård, 1922).

\section{SYSTEMATIC PALAEONTOLOGY}

All figured specimens are housed at the Department of Geology, Lund University (depository acronym LO). Only Treptotreta jucunda and Mongolitbulus aspermachaera $\mathrm{n}$. sp. are described and discussed below. The remaining faunal elements of the assemblage are represented by limited material, some with inadequate preservation and although figured (Fig. 6), are not described in detail. The majority of the identifiable phosphatocopids are well known from the region and have been described in detail elsewhere (e.g. Hinz-Schallreuter, 
1993; Maas et al., 2003). Secondary phosphatized sclerites of trilobites and agnostoids are also represented in the acid resistant residue of the sample. These include pygidia and incomplete thoracic tergites of Parabolina cf. brevispina (Fig. 6.14, 17-21), a pygidium of an unidentified trilobite (Fig. 6.15-16), and cephala, pygidia and thoracic tergites of Agnostus sp. (Fig. 6.9-13). The pygidium assigned to Agnostus sp. differs from the Agnostus pisiformis (Wahlenberg, 1818) and Agnostus (Homagnostus) obesus in having a narrower and shorter axis, particularly expressed in the width and length of the posteroaxis.

Phylum BRACHIOPODA Duméril, 1806

Subphylum LinguliformeA Williams, Carlson, Bruton, Holmer and Popov, 1996

Class Lingulata Gorjansky and Popov, 1985

Order ACROTRETIDA Kuhn, 1949

Superfamily ACROTRETOIDEA Schuchert, 1893

Family ACROTRETIDAE Schuchert, 1893

Genus Treptotreta Henderson and MacKinnon, 1981

Treptotreta JUCUndA Henderson and MacKinnon, 1981

Figures 2-3

1971 Acrotretinae gen. et sp. nov. Henderson in Hall, Playford AND WoOds, pl. CmI, figs $1-5$.

1981 Treptotreta jucunda HENDERSON AND MACKINNON, p. 294, fig. 5A-I.

1987 Treptotreta jucunda BISCHOFF AND PRENDERGAST, p. 51, 58, fig. 7I-K, non 7L.

1996 Treptotreta jucunda ENGELBRETSEN, p. 73, fig. 2A-J.

2006 Treptotreta jucunda ENGELBRETSEN, p. 239, fig. 7M-U. 
Description.-Ventral valve high, broadly conical and on average about $85 \%$ as long as wide and close to half as high as long (about 40\%). Ventral valve circular to transversely elliptical in outline, with a maximum width of $1.94 \mathrm{~mm}$, length of $1.83 \mathrm{~mm}$ and height of $0.931 \mathrm{~mm}$ (Fig. 2.1-2). Anterior and lateral profiles straight, sometimes weakly convex, rarely concave (Fig. 2.14) and slope steeply anteriorly from apex (Fig. 2.13). Ventral pseudointerarea is gently procline (Fig. 2.14), rarely catacline and is flat (Fig. 2.14) to slightly convex in lateral profile. The intertrough is poorly defined (Fig. 2.9-12), deflecting growth lines dorsally (Fig. 2.12). Minute subcircular pedicle foramen (average about $50 \mu \mathrm{m}$ in diameter) entirely enclosed within the larval shell and located at the posterior margin of the larval shell, immediately below the valve apex (Fig. 2.2, 4, 8-10). Ventral interior has an apical process forming a ridge along the posterior and anterior slopes of the valve (Fig. 2.17); the apical process is perforated by an internal pedicle tube near its posterior end (Fig. 2.15, 20). Apical process is slightly concave in lateral profile and broadens anteriorly (Fig. 2.15). Apical pits weakly impressed, situated posterior to the internal pedicle opening but are frequently obscured (Fig. 2.15). The ventral cardinal muscle fields are slightly thickened, located posterolaterally on the posterior slope of the valve.

Dorsal valve flat to weakly convex in lateral profile, frequently displaying a weak fold (Fig. 3.5) and on average about $85 \%$ as long as wide. Dorsal valve with a maximum width of $2.01 \mathrm{~mm}$ and length of $1.96 \mathrm{~mm}$. The dorsal pseudointerarea is orthocline and occupies a third (average 35\%) of the valve width; the median groove is concave (Fig. 3.9-11, 14). Dorsal cardinal muscle fields are large, elongate and suboval, occupying approximately 50\% of the valve width and extending anteriorly about $20-25 \%$ of the valve length (Fig. 3.9, 14). The dorsal median septum is well-developed, not continuous to the pseudointerarea (Fig. 3.10) extending for slightly more than $60 \%$ of the valve length. Median septum is high and triangular, maximum height around midvalve where it projects as a single, undifferentiated 
rod (Fig. 3.10, 14-16). Larval shell of dorsal valve frequently displays two distinct nodes (Fig. 3.6), in rare cases displaying a collar-like structure on the posterior margin of the larval shell (Fig. 3.7). Larval shells on both valves are well defined and range from 140 to $268 \mu \mathrm{m}$ in diameter, circular in shape and are covered by fine, shallow pits (Fig. 3.8). The pitting on the larval shell consists of hemispherical pits that range in diameter from $1.17 \mu \mathrm{m}$ to $2.85 \mu \mathrm{m}$ and decrease in diameter towards the margin of the larval shell (Fig. 2.7-8). Post larval shell covered by variably accentuated, typically marked growth lines.

Material.- Eleven ventral and six dorsal valves are figured with over 100 dorsal and ventral valves retrieved from acid-resistant residues of a limestone sample (Vg2006-3PA) from north of Gudhem quarry, Västergötland, Sweden.

Occurrence.- Treptotreta jucunda has only previously been documented from the 'middle' to 'late' Cambrian (most probably pre-Furongian) of Australia and New Zealand (Henderson and MacKinnon, 1981; MacKinnon, 1983; Bischoff and Prendergast, 1987; Engelbretsen, 1996, 2006). Here we document the first occurrence of the species outside of Gondwana, from the Furongian part of the Alum Shale Formation of Västergötland, southcentral Sweden.

Discussion.- Treptotreta jucunda is only known from a few localities, predominantly from the traditional middle-late Cambrian of Australia where specimens have been documented from the Georgina Basin (Henderson and MacKinnon, 1981), the Wagonga Beds (Bischoff and Prendergast, 1987), the Murrawong Creek Formation (Engelbretsen, 1996) and the Dolodrook River limestones (Engelbretsen, 2006). Treptotreta juncunda with respect to individual abundance, dominates the microfauna of the limestone sample from Västergötland, constituting approximately $60 \%$ of the faunal assemblage. The specimens herein strongly resemble those from the Drumian Mailchange Limestone, Georgina Basin (Henderson and MacKinnon, 1981, figs. 5A-I). The conical ventral valve, indistinct intertrough, a minute 
pedicle foramen enclosed entirely within the larval shell, a distinct apical process that broadens anteriorly and a strong, triangular median septum are all characters indicative of $T$. juncunda. Henderson and MacKinnon (1981) when erecting the genus, briefly discussed the similarities of Treptotreta with other contemporary acrotretid genera, such as Angulotreta Palmer, 1954 and Prototreta Bell, 1938, dismissing taxonomic placement in either genus due to the anterior broadening of the apical process and the lack of a distinct intertrough.

Significantly, the pedicle foramen of Prototreta is not confined within the larval shell and the genus additionally exhibits a triangular dorsal median septum that sometimes becomes digitate or forms a thickened rod or platform at the top (Bell, 1938; Holmer and Popov, 2000), a feature not present in any of the dorsal valves from Västergötland. Angulotreta displays a similar apical process to the $T$. jucunda specimens documented herein, however the type species A. triangularis Palmer, 1954 differs by possessing a complex, surmounting plate in the dorsal valve, a feature absent from the Swedish material and A. postapicalis Palmer, 1954 differs by possessing a simple, triangular median septum. Specimens documented by Popov (1985) from the presently unnamed Furongian formation of the Novaya Zemlya Archipelago as Angulotreta postapicalis shows similarities to Treptotreta jucunda, however without discrimination of the Russian material a detailed comparison is difficult.

The combination of a well-developed, triangular dorsal median septum and pedicle foramen that is entirely enclosed within the larval shell excludes designation to a large number of Cambrian acrotretoid genera. Some of the smaller specimens of $T$. jucunda (e.g. Fig. 2.6-10) resemble the genus Quadrisonia Rowell and Henderson, 1978, documented from the lower Furongian of Australia, Kazakhstan, Antarctica and North America. Quadrisonia generally exhibits a low, subconical to conical ventral valve with an undivided or very shallow intertrough and a pedicle foramen that is entirely enclosed within the larval 
shell (Popov and Holmer, 1994; Holmer and Popov, 2000). Dorsal valve representatives of Quadrisonia however, generally display a low, variably developed dorsal median septa (Popov and Holmer, 1994), a distinct morphological difference when compared with $T$. jucunda. The smaller ventral valve specimens (for example Fig. 2.6-10, maximum width 505 $\mu \mathrm{m}$, length $630 \mu \mathrm{m}$ and height $200 \mu \mathrm{m}$ ) present in this assemblage tend to display a low, subconical shape similar to that of Quadrisonia. The dimensions are also slightly different in these smaller specimens with valve length equal to, or greater than the valve width, contrary to larger specimens where the valve width is consistently greater than the maximum length of the valve. This variation is here interpreted as a result of ontogenetic change, as there appears to be a clear gradation from the low, subconical ventral valves and the larger specimens $(>1$ $\mathrm{mm}$ in width) that are conical in shape with maximum valve length consistently between $83-$ $93 \%$ of the maximum valve width.

There are some slight morphological differences in the Swedish specimens of Treptotreta jucunda and the type material described from the Tasman Formation of Australia (Henderson and Mackinnon, 1981), most notably the shape and profile of the apical process. Specimens from the Tasman Formation display a low, ridge-like apical process, predominantly situated on the posterior valve slope of the ventral valve (Henderson and Mackinnon, 1981, fig. 5A). By contrast the apical process of the specimens described herein is situated predominantly on the anterior slope of the ventral vale and the posterior part of the apical process is divided into two ridges (example Fig. 2.15-17). The sagittal profile of the apical process anterior of the Swedish specimens is somewhat angular, in comparison to the even anterior apical process of the Australian specimens (Henderson and MacKinnon, 1981, fig. 5A). Henderson and MacKinnon (1981) recognised that T. jucunda is a highly variable species, noting extreme variants in the height of the ventral valve and also lateral profile of the apical process. Given the observed morphological variation of the ventral valve, key 
characters of the dorsal valve maybe more useful for taxonomic assessments within the genus. The dorsal valves of the Swedish and Australian specimens of T. jucunda are indistinguishable and consequently the morphological variation seen in the apical process of T. jucunda specimens from Västergötland is herein considered to be a result of intraspecific variation. Treptatreta cf. jucunda has been described from the Sarykumy Formation of the Atamsu Zhamshi terrain in Kazakhstan (Holmer et al. 2001). The illustrated dorsal valves from Kazakhstan show a median septum similar to T. jucunda (see Holmer et al. 2001, pl. 38, figs $1,8,9)$, but other aspects of the morphology both valves are difficult to evaluate due to the generally poor preservation.

Apart from the type species, there is only one other species that can be confidently included in the genus, Treptotreta bella Koneva, Popov and Ushatinskaya, 1990 described from the Furongian of Kazakhstan (see also Popov and Holmer, 1994, figs. 39A-D, 100). Treptotreta bella differs from the type species in having a relatively low and short median septum (Popov and Holmer, 1994, fig. 100D), wide dorsal pseudointerarea that occupies more than half the valve width and deeply impressed cardinal muscle fields in both valves (Popov and Holmer, 1994). Other reports of Treptotreta specimens have either been left in open nomenclature (e.g. Treptotreta sp. nov. Henderson in Henderson et al., 1992) or have been questionably assigned to the genus (Treptotreta? sp. Puura and Holmer, 1993). The validity of Treptotreta conversa Mei, 1993 and T. mutabilis Mei, 1993, documented from the 'middle' Cambrian of China, was questioned by Popov and Holmer (1994) on the basis that both species exhibit a pedicle foramen that is not enclosed within the larval shell. Given the significance of the position of the pedicle foramen in generic and specific classification, the authors agree with Popov and Holmer (1994), leaving the systematic position of the Chinese species in doubt. 
A recent proposed addition to the genus is Treptotreta? socialis (formerly Acrotreta socialis von Seebach, 1865), transferred to the genus by Bruton and Harper (2000, p. 40) based on a combination of features, including a the presence of a long median septum with a surmounting rod, narrow propareas, the presence of a marked groove on the wide ventral pseudointerarea and a distinctive apical process. Treptotreta? socialis has been a widely recognised Cambrian Baltic species, yet it remains taxonomically unstable with the type and topotype material acknowledged to be in urgent need of revision (for historic review see Bruton and Harper, 2000, p. 40-42). The specimens described herein of T. jucunda bear many similarities to the material documented by Bruton and Harper (2000, figs. 7A-G, 8AG) that prompted the proposed reassignment of Acrotreta socialis to Treptotreta. Bruton and Harper (2000) suggested, but deferred a firm, definitive generic reassignment until the type and topotype material is properly revised. Similarities are greatest when comparing dorsal valves, as both species display a circular, flat to weakly convex dorsal valve, with a high, triangular, median septum surmounted by a cylindrical rod and impressed cardinal muscle scars (Bruton and Harper, 2000, fig. 7). The ventral valves of both species are conical with similar dimensions and procline pseudointerarea (see Bruton and Harper, 2000). Differences are subtle and include a more marked median intertrough in $T . ?$ socialis and the length of the dorsal median septum which extends farther in T.? socialis, practically continuing to the anterior margin (compare Fig. 3.10 with Bruton and Harper, 2000, fig. 7G). Based on the strong similarities between the two species, the reassignment of Acrotreta socialis to Treptotreta seems justified based on the specimens described by Bruton and Harper (2000) from the Guzhangian Stage ('middle') Cambrian of Norway, however a definite generic assignment is difficult without scrutiny of the type material. 
Order BRADORIIDA Raymond, 1935

Family MongOLITUbULIDAE n.fam.

Genera included. -Mongolitubulus Missarzhevsky, 1977, ?Rushtonites Hinz, 1987, Tubuterium Melnikova, 2000, Spinospitella Skovsted, Brock and Paterson, 2006.

Diagnosis.- Small (maximum valve length $5.1 \mathrm{~mm}$, individual spines reach a maximum of $3 \mathrm{~mm}$ in length), subamplete to postplete valves with a straight to gently curved dorsal margin. Lateroadmarginal rim variably present, when present entire between cardinal corners, always demarcated from lateral surface by a shallow, continuous furrow. Up to three weakly developed submedian to anterodorsally situated nodes on convex lateral surface. Valve surface smooth, reticulate, spinose or tuberculate. Attached to valve surface are a variable number of long (frequently maximum length of spine exceeds maximum valve length), protruding, hollow spines. Number of spines on each valve varies from a single spine to thirteen (prominent, first-order) spines. Position of individual spines on the bradoriid valve varies from marginal to subcentral. Spines are slender, tapering to a pointed apex and elliptical to circular in cross-section. Spines are straight to curved and covered with reticulate, spinose or rhomboid scale-like protuberances. Numerous smaller second order spines may be present on the first order spines or on other parts of the valve surface.

Discussion.-The ornamented spines of Mongolitubulus Missarzhevsky, 1977 are common constituents of Cambrian shelly fossil assemblages and have been documented from numerous localities around the world (see Topper et al., 2007 and Kouchinsky et al., 2011 for review). Until recently, the biological affinity of such spines was controversial, however discoveries of ornamented spines attached to the valve of bradoriid arthropods (Skovsted and Peel, 2001; Skovsted, 2005; Zhang, 2007; Topper et al. 2007; Kouchinsky et al., 2011) has provided compelling evidence of a bradoriid affinity for this cosmopolitan small shelly fossil taxon. The taxonomic affinity or systematic position of Mongolitubulus and other spine 
bearing genera (e.g. Spinospitella) within the Bradoriida has been less certain. The majority of specimens left unassigned at family-level as a result of an inadequate knowledge of their valve morphology and the fact that their most distinct morphological feature, the possession of a long, protruding, ornamented spine(s) is not considered a diagnostic character in the majority of acknowledged bradoriid families.

Spines are seen as a characteristic feature of two bradoriid families, Duibianellidae and Monasteriidae, described from the 'lower' and 'middle' Cambrian of China and Australia respectively (Shu, 1990; Fleming, 1973; Jones and McKenzie, 1980). The surface of Duibianella Shu, 1990 for instance, is covered with many ornamented spines of various sizes that are sporadically placed over the entire valve (see Zhang, 2007, pls. 7-9). The spines on Duibianella do display a similar ornament when compared to Mongolitubulus and Spinospitella Skovsted, Brock and Paterson, 2006. The shape of the spines however, are vastly different, with the spines present on Duibianella, represented as low, ornamented nodes, rather than the distinct, long spines observed in Mongolitubulus species. The monasteriid, Monasterium oepiki Fleming, 1973 is also characterised by the presence of anterodorsal and posterodorsal spines. No ornament is obvious on the spine surface and the family is further characterised by a curved ridge that extends from and below the anterodorsal spines to the posteromedial region of the valve (Fleming, 1973; Jones and McKenzie, 1980; Melnikova, 1997), a morphological feature not seen in the Mongolitubulidae. A number of bradoriid species from other families sporadically display small and presumably nondiagnostic spines (e.g. Albrunnicola bengtsoni Hinz-Schallreuter, 1993 see Topper et al., 2007, fig. 10E and Kunmingella typical Huo and Shu, 1985, see Hou et al. 2001, fig. 25h, i; Zhang, 2007, pl. 4).

The new family is based on the unique character states of the genus Mongolitubulus, with diagnostic morphological characters focusing on the presence and attachment position of 
one or many, distinct, long, ornamented spines. Species included in the group in addition to the presence of a distinct spine, typically display a relatively simple shield, with little or no lobation (e.g. Tubuterium Melnikova, 2000, Monglitubulus unispinosa, M. reticulatus and M. aspermachaera $\mathrm{n} . \mathrm{sp}$.$) . Tubuterium was questionably assigned to the Monasteriidae by$ Melnikova (2000) but the simple, moderately convex valve exhibiting a long, spine that projects from an anterodorsal node together with the lack of the curved ridge, typical of the monasteriids suggests the genus is better placed within the Mongolitubulidae. Mongolitubulus unialata (Zhang, 2007) from the 'lower' Cambrian of China (formerly Spinella unialata, synonymised with Mongolitubulus in the biogeographic work of Topper et al., 2011) also displays a relatively simple shield and was originally assigned to the Svealutidae. The svealutids are a family of Bradoriida characterised by subamplete to postplete valves, exhibiting a smooth and evenly convex surface with a lateroadmarginal ridge and up to four, generally weakly developed nodes (Siveter and Williams, 1997; Hou et al., 2002; Zhang, 2007). None of the genera included in the Svealutidae display any form of spinose attachment and as the presence of these long, spines is such a prominent and distinct morphological character, the erection of a new family to accommodate these previously taxonomically ambiguous spinose bradoriid species is necessary.

Genus Mongolitubulus Missarzhevsky, 1977

Type species.-Mongolitubulus squamifer Missarzhevsky, 1977.

Other species.-Mongolitubulus henrikseni Skovsted and Peel, 2001, M. unispinosa

Topper, Skovsted, Brock and Paterson, 2007, M. unialata Zhang, 2007, M. reticulatus

Kouchinsky, Bengtson, Clausen, Gubanov, Malinky and Peel, 2011 and M. aspermachaera n. sp. 
Emended diagnosis.- Small (maximum recorded valve length $2.5 \mathrm{~mm}$, individual spines reach a maximum of $3 \mathrm{~mm}$ in length), subamplete to postplete valves with a straight to gently curved dorsal margin. Lateroadmarginal rim variably present, when present entire between cardinal corners, always demarcated from lateral surface by a shallow, continuous furrow. Valve surface convex with up to three weakly anterodorsally developed nodes. Valve surface smooth, reticulate or tuberculate. Variable number of long, hollow spines protrude from valve surface, positioned marginally or subcentrally. Spines are slender, tapering to a pointed apex and elliptical to circular in cross-section. Spines are straight to curved and covered with reticulate, spinose or rhomboid scale-like protuberances.

Discussion.- The documentation of Mongolitubulus-like spines on the Cambrian eodiscoid trilobite Hupeidiscus orientalis Zhang, 1953 from South China has emphasized the taxonomic complications dealing with individual, ornamented spines in Cambrian shelly assemblages. Individual, isolated spines in a faunal assemblage may be difficult to systematically assign on ornament alone, as it is evident that morphologically similar spines probably arose numerous times across many arthropod lineages, indicating functional significance more than taxonomic distinction ( $\mathrm{Li}$ et al., 2012). The genal and axial spines of H. orientalis do display ornament reminiscent of Mongolitubulus spines (Li et al., 2012, fig. 4Q); however, they differ in primary composition, microstructure and absolute size. The largest spine displayed by $H$. orientalis is approximately $818 \mu \mathrm{m}$ in length and $100 \mu \mathrm{m}$ in diameter and on average illustrated spines are about $546 \mu \mathrm{m}$ in length and $72 \mu \mathrm{m}$ in maximum width (Li et al., 2012, fig. 4). Documented spines of Mongolitubulus species are consistently larger in terms of length and width; spines of $M$. henrekseni reach $3 \mathrm{~mm}$ in length and $210 \mu \mathrm{m}$ in maximum width (Skovsted and Peel, 2001), M. unispinosa exhibits a spine of $1.23 \mathrm{~mm}$ in length and $157 \mu \mathrm{m}$ in width (Topper et al., 2007), spines of $M$. reticulatus reach a maximum of $3 \mathrm{~mm}$ in length and $250 \mu \mathrm{m}$ in width (Kouchinsky et al., 
2011), spines of M. aspermachaera reach a maximum length of $2.5 \mathrm{~mm}$ and $214 \mu \mathrm{m}$ in width (Fig. 5.17-18) and spines referred to M. squamifer reach a maximum of $2.3 \mathrm{~mm}$ in length and $300 \mu \mathrm{m}$ in width (see Skovsted and Peel, 2001; Wrona, 2004; Topper et al., 2007).

The genus Mongolitubulus was established by Missarzhevsky (1977) based on four phosphatic, tapering, ornamented spines from the lower Cambrian of Mongolia. The fragmentary spines showed no signs of an expanded base (Missarzhevsky, 1977), a feature present in spines belonging to other members of the Mongolitubulus genera. To date, no specimens confidently assigned to $M$. squamifer have been found attached to the valve of a bradoriid arthropod and as a result there is some uncertainty regarding the biological affinities of the type species. The absence of a flared base however, should not automatically dismiss a biological affinity with bradoriid arthropods. It would be safe to assume that the majority of spines would flare at the point of attachment with the carapace, valve or sclerite of a particular organism and this is indeed true for the Mongolitubulus-like spines on the trilobite H.orientalis (Li et al. 2012, fig. 4I, N, P, Q). The valves of bradoriids are typically weakly mineralized (see Topper et al., 2007; Zhang, 2007), the associated spines in comparison appear to be more strongly mineralized, showing no signs of distortion or folding. If the zone where mineralisation begins is not exactly at the base of the spine, but a short distance up the spine then the spine base would not necessarily be preserved. The base of $M$. aspermachaera n. sp. spines are variably preserved, with some specimens exhibiting no expanded, flared base (Fig. 5.14, 22), and the same is true for the absolute majority of specimens in M. henrikseni from Greenland (Skovsted \& Peel 2001). There is some doubt over the biological affinity of the type species, M. squamifer, however the absence of a flared base should not be the sole morphological feature that preclude the species from the Bradoriida and additional information should be sought. The microstructure of $M$. squamifer has been extensively studied and is frequently compared directly with bradoriid valve 
microstructures that show strong similarities (see Skovsted and Peel, 2001; Wrona 2004, 2009). Spines are characterised by an outer, dense layer and a distinctly fibrous inner layer (see Melnikova, 2000; Skovsted and Peel, 2001, fig. 2A, D; Wrona, 2004, figs 23-24, 2009, fig. 13). Specimens of M. squamifer documented from 'early' Cambrian glacial erratics of Antarctica display a third, thin internal layer which is very delicate and infrequently preserved (Wrona, 2009, fig. 13B $\mathrm{B}_{1}-\mathrm{B}_{2}$ ) similar to that of many bradoriid valves (see Zhang, 2007, p. 105). Spines are also phosphatic in primary composition, dissimilar to the calcitic exoskeleton of eodiscoid trilobites. In the Swedish collections, trilobite specimens that exhibit spinose attachments (Fig. 6.14-24) have been retrieved from the same stinkstone as the documented specimens of $M$. aspermachaera. The trilobite pygidia and thoracic tergites preserved in the assemblage, additionally display a tuberculate ornament that displays some similarities to the ornament of M. aspermachaera. However, the similarities are nothing but superficial, as the spines are much shorter and stouter (Fig. 6.22-24) in comparison to $M$. aspermachaera. The external ornament, although tuberculate in nature (Fig. 6.16, 21), does not show the same structures as the bradoriid valves and spines and the preservation is also highly disparate. Li et al. (2012) cautions the use of the generic name Mongolitubulus, until the identity of the type species can be accurately clarified. The microstructure, primary composition and general size in addition to the spatial and temporal distribution of specimens referred to M. squamifer (Skovsted and Peel, 2001; Wrona, 2004, 2009; Skovsted, 2005; Topper et al., 2007, Kouchinsky et al., 2011) provides convincing evidence for a bradoriid arthropod affinity for the type species, permitting systematic assignment to the Mongolitubulidae.

Similarities in ornament exhibited by spines referred to Mongolitubulus, Rushtonites Hinz, 1987 from the Lower Cambrian of England and spines of the bradoriid arthropod Tubuterium Melnikova, 2000 from the Cambrian of Siberia has been recognised by numerous 
authors (e.g. Melnikova, 2000; Skovsted and Peel, 2001; Skovsted, 2005; Skovsted et al., 2006; Kouchinsky et al., 2011). The strong similarities prompted Kouchinsky et al. (2011) to recognise Tubuterium as a junior synonym of Rushtonites and Rushtonites in turn as a junior synonym of Mongolitubulus, despite the noted differences in ornamentation between the holotypes of Tubuterium and Rushtonites. This view is not supported here, on the basis that Rushtonites is exclusively known from isolated, ornamented spines and that ornament alone is not seen as a reliable and diagnostic characteristic. The synonymy of Rushtonites with Tubuterium should be reconsidered until further supporting evidence is ascertained. Rushtonites is here questionably placed in the Mongolitbulidae based on the similarities with Mongolitubulus and Tubuterium but the assignment is tentative and awaits affirmation.

Mongolitubulus aspermachaera $\mathrm{n} . \mathrm{sp}$.

Figures 4-5

Diagnosis.- Moderately inflated, subamplete valves exhibiting a distinct, low lateroadmarginal ridge, entire between cardinal corners and separated from the lateral surface by a continuous furrow. Anterodorsal or posterodorsal lobation or sulci absent. Outer surface covered with raised, subcircular structures. Spine long, subcircular in cross-section, tapering to a pointed apex. Outer surface of spine covered by raised, subcircular structures.

Description.-Small (maximum length of valve $1.97 \mathrm{~mm}$ ), moderately inflated subamplete valve. Lateroadmarginal ridge is broad and low, entire between cardinal corners and is paralleling the valve margin separated from convex lateral surface by a shallow and continuous furrow (Fig. 4.5). Dorsal margin is missing on both specimens with no lobation evident on the remainder of the valves. Outer surface is covered by raised, ovoid to subcircular, structures (diameter 12-20 $\mu \mathrm{m}$ ) that are unevenly distributed over the entire 
surface of the valve (Fig. 4.6-8, 12-16). There is a wrinkling of the valve surface between the raised subcircular structures (Fig. 4.6). Shell structure consists of four layers. The surface of the valve and spines are covered by a thin, phosphatic coating, which is frequently worn away (Fig. 4.15, 5.26). The outer layer exhibits the raised, subcircular structures that are hollow (Fig. 4.20), not continuing to valve interior and interrupted by a thin, solid layer (Fig. $4.13,20)$. Subcircular, raised structures on the valve exterior are mirrored in the valve interior (innermost valve layer) by dome-shaped phosphatic pads (Fig. 4.17). Between these two shell layers is a layer dotted by minute pores that align with the external raised structures and the internal dome-shaped pads (Fig. 4.18-20). Spines are straight to slightly curved and taper to a pointed apex (Fig. 5.17); frequently exhibiting a strongly recurved tip, resembling a hook (Fig. 5.12-15). Spines are long (maximum length $2.5 \mathrm{~mm}$, Fig. 5.17); ovoid to circular (compare Fig. 5.20 and Fig. 5.22) in cross section (maximum diameter $214 \mu \mathrm{m}$ ). The abapical end of the spine is generally flared (Fig. 5.9-11, 16) and always broken. Some flared bases still display remnants of the valve surface (Fig. 5.16). Outer surface of spines are covered by raised, ovoid to subcircular structures (diameter $8-17 \mu \mathrm{m}$ ) that are unevenly distributed over the entire surface (Fig. 5.8, 19, 21, 24-26). Ornament is generally more densely packed towards the flared base, only sparsely packed towards the apex of the spine (Fig. 5.15). There is a wrinkling of the surface between the raised subcircular structures, more frequently observed towards base of the spine (Fig. 5.2, 8). Shell structure identical to that of valve, hollow, raised, external structures are sealed internally by dome-shaped phosphatic pads (Fig. $5.3-4,11$ ), separated by two layers, including a layer displaying minute pores (Fig. 5.4) and a thin, solid layer (Fig. 5.23). Raised, subcircular structures display a flat top, parallel to the spine surface (Fig. 5.19, 26) however sometimes, raised structures are cut obliquely at an approximate angle of $45^{\circ}$ to the spine surface (Fig. 5.21, 25). 
Etymology. - Derived from the Latin prefix asper, meaning scale and machaera, meaning saber. In reference to the ornamented spine of the bradoriid arthropod.

Types.- Holotype: LO11434T(Fig. 4.1-8); paratypes: LO114345T (Fig. 4.9-11), LO11440T (Fig. 4.21-22), LO11441T (Fig. 5.1-4), LO11445T (Fig. 5.12-13), LO11446T (Fig. 5.14-15), LO11448T (Fig. 5.17-19).

Occurrence. -Locally derived boulder of whitish to grey limestone north of an old quarry at Gudhem in the Falbygden area, Västergötland, south-central Sweden. Lower part of the Furongian, Olenus truncatus and Parabolina brevispina zones.

Discussion. - Mongolitubulus aspermachaera n. sp. is represented in the Västergötland faunal assemblage by isolated bradoriid valves and numerous individual, ornamented spines. Isolated spines are relatively common in the assemblage with over 70 individual spines examined; however complete valves are rare, with only a few specimens displaying margins preserved. The large majority of $M$. aspermachaera valves are either fragmentary or heavily deformed and crinkled, a frequent feature of bradoriid specimens due to their weakly mineralised valves (Topper et al., 2007; Zhang 2007; Kouchinsky et al., 2011). Fragments can be readily identified as M. aspermachaera due to the characteristic exterior valve ornament, an ornament not displayed by any previously documented bradoriid species. The posterodorsal margin of M. aspermachaera is always absent (Fig. 4.1-5), pinpointing the attachment location of the spine. The exact number of spines present on each valve is uncertain, however based on the size of the associated spines (average basal width $200 \mu \mathrm{m}$, flared bases displaying remnants of valve (Fig. 5.16) reach up to $540 \mu \mathrm{m}$ in width) and the space available on the absent posterodorsal margin (approximately $800 \mu \mathrm{m}$ of the dorsal margin on the holotype), the presence of a single spine is most likely.

Mongolitubulus aspermachaera represents the youngest member of the Mongolitubulidae with all other documented species confined to provisional Cambrian series 
2 and 3 (Skovsted and Peel, 2001; Skovsted et al., 2006; Topper et al., 2007; Zhang, 2007; Kouchinsky et al., 2011). Mongolitubulus aspermachaera exhibits a relatively simple convex, inflated valve similar to other species of Mongolitubulus and most likely bears a single, prominent spine similar to M. unispinosa (Topper et al., 2007) and M. unialata (Zhang, 2007). The latter two species though, display a single, subcentrally placed spine, dissimilar to the marginally placed spine of $M$. aspermachaera. Similarities can also be drawn with $M$. reticulatus from Cambrian Stage 5 of Siberia, both species displaying simple, convex valves with long, tapering spines that frequently display a recurved tip (Kouchinsky et al., 2011, figs 33-34). The position of the spines on M. reticulatus is uncertain but the smooth portions of the preserved valves indicate that the spines were not centrally placed (Kouchinsky et al., 2011) and the spines were potentially located in a marginal position similar to that of $M$. aspermachaera. The Cambrian Stage 5 Siberian species exhibits a postplete valve with a smooth to reticulate ornament consisting of longitudinally extended polygons (Kouchinsky et al., 2011) and M. aspermachaera differs by possessing a subamplete valve, a broad marginal rim and a distinctive raised, subcircular ornament (Fig. 4.6-8). Differences with $M$. henrekseni are much more apparent, with the Greenland species exhibiting multiple spine bases (up to 13 major or first order spines) on the central parts of the valves and a large

number of smaller (second order) spine bases along the valve margins (Skovsted and Peel, 2011, fig. 4; Skovsted, 2005, fig. 1).

\section{SPINOSE BRADORIIDS AND BRADORIID SHELL STRUCTURES}

The relationship between isolated, ornamented Cambrian phosphatic spines and bradoriid arthropods was first suggested over a decade ago (Melnikova, 2000), a relationship based on the presence of bradoriid valves and Mongolitubulus-like spines occurring on the 
same bedding surfaces. More definitive evidence has been presented since, with spinebearing bradoriid arthropods documented from a variety of Cambrian locations around the globe (Skovsted and Peel, 2001; Skovsted, 2005; Zhang, 2007; Topper et al. 2007; Kouchinsky et al., 2011). The spine-bearing eodiscoid trilobite documented from South China (Li et al., 2012) has emphasized the potential taxonomic complications when dealing with isolated, ornamented spines that may belong to a variety of groups within the Ecdysozoa. Isolated ornamented spines will no doubt continue to be found in Cambrian faunal assemblages and care must be taken in their taxonomic assessment. Species differentiation based solely on ornament is no longer suitable for systematic classification; many other characteristics such as microstructure, faunal association, size and shape should also be employed in their taxonomic appraisal and without substantial evidence supporting an association with a particular organism, whether bradoriid arthropod or trilobite, such spines should be left in open nomenclature.

Some assemblages of isolated, ornamented spines referred to Mongolitubulus display morphological features that vary from the material described herein. Dzik (2003) described one of the richest deposits known of isolated, ornamented spines, recovering 3815 specimens from only $1 \mathrm{~kg}$ of limestone, from the 'lower' Cambrian Shabakhty Formation of Kazakhstan. The spines displayed considerable variability, expressed predominantly in crosssection, curvature and surface ornamentation (Dzik, 2003). The spines were referred to the type species, M. squamifer, although Dzik (2003) noted that the Kazakh specimens were difficult to assign taxonomically and exhibited ornamental differences when compared to the holotype from Mongolia. The most noticeable and perhaps significant difference between the Kazakh spines and all of the Mongolitubulus spines described and discussed herein, is that of size. Dzik (2003) documents an extreme variation in size (Dzik 2003, text-fig. 4) with the width of spines ranging from approximately $230 \mu \mathrm{m}$ to over $1.5 \mathrm{~mm}$. Length of spines also 
vary considerably with figured specimens ranging from approximately $2 \mathrm{~mm}$ (Dzik, 2003, text-fig. 2E) to over $8 \mathrm{~mm}$ (Dzik, 2003, text-fig. 2B) with the estimated length of the largest spines in the assemblage reported at 18-20 mm (Dzik, 2003).

The sizes reported by Dzik (2003) greatly exceed those reported for any Mongolitubulus species, with M. henrekseni possessing the largest spines otherwise documented at $3 \mathrm{~mm}$ in length and $210 \mu \mathrm{m}$ in maximum width (Skovsted and Peel, 2001). The size of the spines documented by Dzik (2003) places some doubt over their affiliation with bradoriid arthropods. Even when considering that the length of attached spines in Mongolitubulus species are frequently longer than the maximum length of the associated bradoriid valves (e.g. M. henrekseni, M. reticulatus and $M$. aspermachaera $\mathrm{n}$. sp.), the size of the individual spines documented by Dzik (2003), are only comparable to the largest of all known bradoriids (17.5 mm in length; Siveter \& Williams, 1997). However, in general bradoriid arthropod valves are considerably smaller with the largest member of the Mongolitubulidae, Tubuterium, reaching $5.1 \mathrm{~mm}$ in length and the valves of species of Mongolitubulus only reaching $2.5 \mathrm{~mm}$ in length. The size of the spines and co-occurrence with sclerites of Microdictyon Bengtson, Matthews \& Missarzhevsky in Missarzhevsky \& Mambetov, 1981 prompted Dzik (2003) to suggest an affiliation with 'early' Cambrian lobopodians, such as Xenusion Pompeckj, 1927 and Microdictyon. Using the relative proportions of spines and associated faunal elements to assist with biological affiliation in this case is unhelpful, as the sample from Kazakhstan is dominated by isolated spines, constituting $95.7 \%$ of the assemblage; bradoriid valves constitute $1 \%$ with Microdictyon specimens only constituting $0.4 \%$ of the entire assemblage (Dzik, 2003). Bradoriid valves associated with the isolated spines from Kazakhstan are few and at approximately $1 \mathrm{~mm}$ in length (Dzik, 2003, text-fig. 8A-B), do not provide much support for a bradoriid affinity for these specimens. The microstructure of the Kazakh spines need further exploration and 
although the fibrous inner surface (Dzik 2003, text-fig. 3C) is comparable to that of $M$. squamifer (see Skovsted and Peel 2001; Wrona 2004, 2009) and the ornament resembles other documented bradoriid arthropod spine ornaments, the relative size of the specimens, their isolated nature and their lack of associated bradoriid valves, suggest exclusion from the Mongolitubulidae, awaiting further investigation.

In the absence of articulated spinose bradoriid arthropods, a useful tool for potentially identifying or at least elucidating the association of isolated spines (such as those documented by Dzik, 2003) with a particular organism is microstructure. Microstructure has been extensively employed in a variety of faunal groups (e.g. brachiopods, see Williams, 1970) for taxonomic purposes and to help clarify evolutionary relationships. Shell microstructure is also becoming increasingly used in studies regarding the evolutionary relationships of Cambrian shelly faunas. Recently, the shell microstructure of 'early' Cambrian tommotiid taxa, Paterimitra Laurie, 1986 and Eccentrotheca Landing, Nowlan and Fletcher, 1980 was utilised to demonstrate a relationship with paterinid brachiopods (see Balthasar et al., 2009; Topper et al., in press). Microstructural details of the enigmatic 'early' Cambrian taxon Sunnaginia Missarzhevsky, 1969 shows characteristics reminiscent of tannuolinids, potentially placing the genus close to the node defining crown-Brachiopoda (Murdoch et al., 2012), such studies underlining the potential significance of microstructural information.

The microstructure of bradoriid arthropod valves has been investigated for nearly half a century (e.g. Öpik, 1968; Fleming, 1975; Huo and Shu, 1985; Shu, 1990; Zhang, 2007) yet the finer microstructural details remain unclear. The microstructure of the new species described herein is quite distinctive and much more complex when compared to the simple layered microstructure documented from the majority of Mongolitubulus species to date (Skovsted and Peel, 2001; Wrona 2004, 2009; Kouchinsky et al., 2011). Significantly the valves and individual spines of $M$. aspermachaera display an identical microstructure that 
consists of four layers. The outer surface is covered by raised, ovoid to subcircular, hollow structures (e.g. Fig. 4.16) frequently separated by a wrinkling that predominantly occurs towards the base of the spine (Fig. 5.2,8) and in the furrow paralleling the valve margin (Fig. 4.6). Immediately underlying this layer is a thin, solid layer (Fig. 4.20) that exhibits small dimples (Fig. 4.7) that show a similar distribution to the raised, subcircular structures of the outer layer. Underneath this layer is a layer displaying minute pores (Fig. 4.18-20) that align with the subcircular structures on the valve exterior (Fig. 4.20). The innermost layer consists of dome-shaped phosphatic pads (Figs 4.17, 5.3-4, 11) that internally mirror the external, raised, subcircular structures.

The microstructure of $M$. aspermachaera displays an increased complexity when compared to the simple three layer laminate structure discussed by Zhang (2007) and Wrona (2009). Despite the number of studies regarding the microstructure of bradoriid valves, the structure of the large majority of bradoriid arthropod valves have not been documented and it is unknown if the microstructure of M. aspermachaera exists in other species. Previous microstructural studies have also focused on 'early' Cambrian specimens (Huo and Shu, 1985; Shu, 1990; Zhang, 2007; Wrona, 2009) and it remains unclear whether bradoriid valve microstructure increased in complexity during the Cambrian as potentially evident by the intricate laminate microstructure displayed by younger, Furongian specimens of $M$. aspermachaera. The microstructure of bradoriid arthropod valves represents a significant, yet understudied morphological character that potentially may be significant for taxonomic works in the future.

\section{ACKNOWLEDGMENTS}

This work has been supported by grants from the Carlsberg Foundation (Timothy P. Topper), the Danish Council for Independent Research (David A. T. Harper) and Magnus Bergvalls 
Stiftelse (Per Ahlberg). We thank John ('Jompa') Ahlgren, Hällekis, Västergötland, for collecting and donating the limestone sample to the Department of Geology, Lund University. Git Klintvik Ahlberg, Lund, skilfully processed the limestone sample and picked the microfossils. The manuscript benefited from the constructive reviews of $\mathrm{xxx}$ and $\mathrm{xxx}$.

\section{REFERENCES}

Ahlberg, P. 1989. Cambrian stratigraphy of the När 1 deep well, Gotland. Geologiska Föreningens i Stockholm Förhandlingar, 111: 137-148.

AhlBerg, P. 2003. Trilobites and intercontinental tie points in the Upper Cambrian of Scandinavia. Geologica Acta, 1:127-134.

Ahlberg, P. And J. AhlgRen. 1996. Agnostids from the upper Cambrian of Västergötland, Sweden. GFF, 118:129-140.

Ahlberg, P., H. Szaniawski, E. N. K. Clarkson And S. Bengtson. 2005. Phosphatised olenid trilobites and associated fauna from the Upper Cambrian of Västergötland, Sweden. Acta Palaeontologica Polonica, 50:429-440.

Ahlberg, P., N. Axheimer, L. E. Babcock, M. E. Eriksson, B. Schmitz And F. TERFELT. 2009. Cambrian high-resolution biostratigraphy and carbon isotope chemostratigraphy in Scania, Sweden: first record of the SPICE and DICE excursions in Scandinavia. Lethaia, 42:2-16.

ANDRES, D. 1969. Ostracoden aus dem mittleren Kambrium von Öland. Lethaia $2: 165-180$.

Angelin, N. P. 1851. Palaeontologia Svecica. I: Iconographia Crustaceorum Formationis Transitionis. Lund, 24 p.

Angelin, N. P. 1854. Palaeontologia Scandinavia. I: Crustacea Formationis Transitionis. T. O. Weigel, Leipzig, 21-92 p. 
Axheimer, N. AND P., AhlBerg. 2003. A core drilling through Cambrian strata at Almbacken, Scania, S. Sweden: trilobites and stratigraphical assessment. GFF, 125:139-156.

Axheimer, N., M. E., Eriksson, P., Ahlberg, And A., Bengtsson. 2006. The middle Cambrian cosmopolitan key species Lejopyge laevigata and its biozone: New data from Sweden. Geological Magazine, 143:447-455.

BELL, W. C. 1938. Prototreta, a new genus of brachiopod from the Middle Cambrian of Montana. Papers of the Michigan Academy of Science, Arts \& Letters, 23:403-408.

BELT, T. 1867. On some new trilobites from the Upper Cambrian rocks of North Wales. Geological Magazine, 4:294-295.

Bischoff, G. C. O. And E. I. Prendergast. 1987. Newly-discovered Middle and Late Cambrian fossils from the Wagonga Beds of New South Wales, Australia. Neus Jahrbuch für Geologie und Paläontologie, Abhandlung, 175:39-64.

BoECK, C. 1838. Uebersicht der bisher in Norwegen gefundenen Formen der Trilobiten, p. 138-145. In B. M. Keilhau (ed), Gaea Norvegica, Johan Dahl, Chistiania.

Bruton, D. L. AND D. A. T., HARPER. 2000: A mid-Cambrian shelly fauna from Ritland, western Norway and its palaeogeographic implications. Bulletin of the Geological Society of Denmark, 47:29-51.

BRÜNNICH, M. T. 1781. Beskrivelser over trilobiten, en dyreslaegt og dens arter med en ny arts aftegning. Nye Samling af det kongelige Danske Videnskabers Selskabs Skrifter, $1: 384-395$.

DALman, J. W. 1827. Om palaeaderna eller de så kallade trilobiterna. Kongliga Svenska Vetenskaps-Academiens Handlingar 1826:113-152, 226-294. 
Dies Álvarez, M. E., R. Gozalo, P. Cederström, And P. Ahlberg. 2008. Bradoriid arthropods from the lower-middle Cambrian of Scania, Sweden. Acta Palaeontologica Polonica, 53:647-656.

DUMÉRIL, A. M. C. 1806. Zoologie analytique, ou method naturelle de Classification des animaux. Allais, Paris, 344 p.

DZIK, J. 2003. Early Cambrian lobopodian sclerites and associated fossils from Kazakhstan. Palaeontology, 46:93-112.

Engelbretsen, M. J. 1996. Middle Cambrian lingulate brachiopods from the Murrawong Creek Formation, north-eastern New South Wales. Historical Biology, 11:69-99.

Engelbretsen, M. J. 2006. Early Late Cambrian lingulate brachiopods from the Dolodrook River limestones, eastern Victoria. Memoirs of the Association of Australasian Palaeontologists, 32:225-246.

FLEMING, P. J., 1973. Bradoriids from the Xystridura Zone of the Georgina Basin, Queensland. Publications of the Queensland Geological Survey 356, Professional Papers, 31:1-9.

Ghobadi Pour, M., M. Williams, And L. E. Popov. 2007. A new Middle Ordovician arthropod fauna (Trilobita, Ostracoda, Bradoriida) from the Lashkarak Formation, Eastern Alborz Mountains, northern Iran. GFF, 129:245-254.

GORYANSKY, V. YU AND L. E. POPOV. 1985. Morfologiya, systematicheskoe polozheniye I proiskhozhdeniye bezzamkovykh brachiopods karbonatnoy rakovinoy. Paleontologischeskiy Zhurnal, 3:3-14.

Henderson, R. A. AND D. I. MACKinnON. 1981. New Cambrian inarticulate Brachiopoda from Australasia and the age of the Tasman Formation. Alcheringa, 5:289-309. 
Henderson, R. A, F. Debrenne, A. J. Rowell, And G. F. Webers. 1992. Brachiopods, archaeocyathids, and Pelmatozoa from the Minaret Formation of the Ellsworth Mountains, West Antarctica. Geological Society of America, Memoire 170:249-267.

Henningsmoen, G. 1957. The trilobite family Olenidae with description of Norwegian material and remarks on the Olenid and Tremadocian Series. Skrifter utgitt av Det Norske Videnskaps-Akademi i Oslo, I. Matematisk-Naturvidenskapelig Klasse, 1957(1);1-303.

Hill, D., G. Playford, G., AND J. T. Woods. (eds). 1971. Cambrian fossils of Queensland. Queensland Palaeontographical Society, Brisbane, 32p.

HINZ, I. 1987. The Lower Cambrian microfauna of Comley and Rushton, Shropshire/England. Palaeontographica, Abteilung A, 198:41-100.

HINZ-SCHALLREUTER, I., 1993. Cambrian ostracods mainly from Baltoscandia and Morocco. Archiv für Geschiebekunde, 1:369, 370, 385-448.

Holmer, L. E. and L. E. PoPOv. 2000. Order Acrotretida, p. 97-136. In R. C. Moore and R. L. Kaesler (eds.), Treatise on Invertebrate Paleontology, Pt H, Brachiopoda (revised), Vol. 2. Geological Society of America and University of Kansas Press, Lawrence. Holmer, L. E., L. E. Popov, S. P. Koneva And M. G. BAsSeTt. 2001. Cambrian - early Ordovician brachiopods from Malyi Karatau, the western Balkhash region, and Tien Shan, Central Asia. Special papers in Palaeontology, 65: 180 pp.

Hou X. G., D. J. Siveter, M. Williams, AND X.G. Feng. 2002. A monograph of the bradoriid arthropods from the Lower Cambrian of SW China. Transactions of the Royal Society of Edinburgh: Earth Sciences, 92:347-409.

Huo, S. C AND D. G. SHu. 1985. Cambrian Bradoriida of South China. Northwest University Press. Xi'an. 251 p. (In Chinese) 
Jones, P. J. AND K. G. McKenZIE. 1980. Queensland Middle Cambrian Bradoriida (Crustacea): new taxa, palaeobiogeography and biological affinities. Alcheringa, $4: 203-225$.

Koneva, S. P., L. E. Popov, G. T. Ushatinskaya, AND N. V. EsaKova. 1990. Bezzamkovye brakhiopody (akrotretidy) i mikroproblematiki iz verkhnego kembriya severo-vostochnogo Kazakhstana. In L.N. Repina (ed.), Biostratigrafiya i paleontologiya kembriya Severnoj Azii. Trudy Instituta Geologii i Geofiziki Akademii Nauk SSSR, Sibirskoe Otdelenie 765, 1:1-70.

Kouchinsky, A., S. Bengston, S. Clausen, A. Gubanov, J. M. Malinky, and J. S. PEEL. 2011. A Middle Cambrian fauna of skeletal fossils from the Kuonamka Formation, northern Siberia. Alcheringa, 35:123-189.

KuHN, O. 1949. Lehrbuch der Paläozoologie. E. Schweizerbart, Stuttgart, 326 p.

LANDing, E., G. S. Nowlan, AND T. P. FletChER. 1980. A microfauna associated with Early Cambrian trilobites of the Callavia Zone, northern Antigonish Highlands, Nova Scotia. Canadian Journal of Earth Sciences, 17:400-418.

LAURIE, J.R. 1986. Phosphatic fauna of the Early Cambrian Todd River Dolomite, Amadeus Basin, central Australia. Alcheringa, 10:431-454.

Li, G. X., M. Steiner, M. Y. ZhU, AND X. Zhao. 2012. Early Cambrian eodiscoid trilobite Hupeidiscus orientalis from South China: ontogeny and implications for affinities of Mongolitubulus-like sclerites. Bulletin of Geosciences, 87:159-169.

MaAs, A., D. WALOSZEK, AND K. J. MÜLLER. 2003. Morphology, ontogeny and phylogeny of the Phosphatocopina (Crustacea) from the Upper Cambrian "Orsten" of Sweden. Fossils and Strata, 49:1-238.

MEI, S. 1993. Middle and Upper Cambrian inarticulate brachiopods from Wanxian Hebei, North China. Acta Palaeontologica Sinica, 32:400-429. 
Melnikova, L. M. 2000. A new genus of Bradoriidae (Crustacea) from the Cambrian of Northern Eurasia. Paleontologicheskii Zhurnal, 34:180-185.

Melnikova, L. M., D. J. Siveter, AND M. Williams. 1997. Cambrian Bradoriida and Phosphatocopida (Arthropoda) of the former Soviet Union. Journal of Micropalaeontology, 16:179-191.

MiSSARZHEVSKY, V. V. 1977. Konodonty (?) i fosfatnye problematiki kembriya Mongolii i Sibiri. In Bespozvonochnye Paleozoya Mongolii,. Trudy Sovmestaya SovetskoMongolskaya Paleontologicheskaya Ekspeditsiya, 10-19. (In Russian)

MissarzHeVsKy, V. V. AND A. M. MAMBETOV. 1981. Stratigrafia I fauna pogranichynch sloiev kembria I dokembria Malogo Karatau. Trudy Geologicheskogo Instituta AN SSR, 326: 1-91.

Moberg, J. C. And C. O. Segerberg. 1906: Bidrag till kännedomen om Ceratopyge regionen med särskild hänsyn till dess utveckling i Fogelsångstrakten. Lunds Universitets Årsskrift, Ny följd, 2:1-113.

Murdock, D . J. E., P. C. J. Donoghue, S. Bengtson, And F. Marone. 2012. Ontogeny and microstructure of the enigmatic Cambrian Tommotiid Sunnaginia Missarzhevsky, 1969. Palaeontology, 55:1-16.

MÜLLER, K. J. AND D. WALOSSEK. 1985. A remarkable arthropod fauna from the Upper Cambrian "Orsten" of Sweden. Transactions of the Royal Society of Edinburgh: Earth Sciences 76:161-172.

MÜlLER, K. J. AND D. WALOSSEK. 1987. Morphology, ontogeny, and life habit of Agnostus pisiformis from the Upper Cambrian of Sweden. Fossils and Strata, 23:1-124.

MÜLLER, K. J. AND D. WALOSSEK. 1988. External morphology and larval development of the Upper Cambrian maxillopod Bredocaris admirabilis. Fossils and Strata, 23:1-70. 
NiElsen, A. T. AND N. H. Schovsbo. 2006. Cambrian to basal Ordovician lithostratigraphy in southern Scandinavia. Bulletin of the Geological Society of Denmark, 53:47-92.

ÖPIK, A. A. 1968. Ordian (Cambrian) Crustacea Bradoriida of Australia. Bulletin of the Bureau of Mineral Resources, Geology and Geophysics, 103:1-44.

PALMER, A. R. 1954. Faunas of the Riley Formation in central Texas. Journal of Paleontology, 28:709-786.

POMPECKJ, J. F. 1927. Ein neues Zeugnis uralten Lebens. Paläontologische Zeitschrift, 9:287-313.

PoPOv, L. E 1985. Kembriiskiye bezzamkovyye brakhiopody iz severo-zapadnoi chasti Yuzhnogo ostrova arkhipelaga Novaya Zemlya, p. 17-30.. In V. I. Bondarev (ed.). Stratigrafiya i fauna paleozoya Novoi Zemli. Sevmorgeologiya, Leningrad (In Russian).

Popov, L. E. AND L. E. Holmer. 1994. Cambrian-Ordovician lingulate brachiopods from Scandinavia, Kazakshstan and South Ural Mountains. Fossils and Strata, 35:1--154.

PUURA, I. AND L.E. HolmER. 1993: Lingulate brachiopods from the Cambrian-Ordovician boundary beds in Sweden. GFF, 115:215-237.

RAYMOND, P. E. 1935. Leanchoilia and other mid-Cambrian Arthropoda. Bulletin of the Museum of Comparative Zoology, 76:205-230.

Rowell, A. J. AND R. A. Henderson. 1978. New genera of acrotretids from the Cambrian of Australia and United States. University of Kansas Paleontological Contributions, 93:1-12.

SCHUCHERT, C. 1893. A classification of the Brachiopoda. American Geologist, 11:141-251. SEEBACH, K. VON. 1865. Beiträge zur Geologie der Insel Bornholm. Zeitschrift der Deutschen geologischen Gesellschaft, 17:338-347. 
Shu Degan. 1990. Cambrian and Lower Ordovician Bradoriida from Zhenjiang, Hunan and Shaanxi Provinces. Northwest University Press, Xian. 90 p.

Siebold, C. T. E And H. StanniUs. 1845. Lehrbuch der Vergleichenden Anatomie. Con Veit, Berlin.

Siveter, D. J., AND M. WiLliams. 1997. Cambrian bradoriid and phosphatocopid arthropods of North America. Special Papers in Palaeontology, 57:1-69.

Skovsted, C. B. 2005. Carapace of the bradoriid arthropod Mongolitubulus from the Early Cambrian of Greenland. GFF, 127:217-220.

Skovsted, C. B., G. A. Brock, And J. R. Paterson. 2006. Bivalved arthropods from the Lower Cambrian Mernmerna Formation of South Australia and their implications for the identification of Cambrian 'small shelly fossils'. Memoirs of the Association of Australasian Palaeontologists, 32:7-41.

Skovsted, C. B. AND J. S. PeEL. 2001. The problematic fossil Mongolitubulus from the Lower Cambrian of Greenland. Bulletin of the Geological Society of Denmark, $48: 135-147$.

Streng, M., J. O. R. Ebbestad, And M. MoczydŁowska. 2008. A Walcottella-like bradoriid (Arthropoda) from the lower Cambrian of Sweden. GFF, 130:11-19.

TERFELT, F. 2003. Upper Cambrian trilobite biostratigraphy biostratigraphy and taphonomy at Kakeled on Kinnekulle, Västergötland, Sweden. Acta Palaeontologica Polonica 48:409-416.

Terfelt, F., M. E. Eriksson, P. Ahlberg, And L. E. BABCOCK. 2008. Furongian Series (Cambrian) biostratigraphy of Scandinavia - a revision. Norwegian Journal of Geology 88:73-87. 
Terfelt, F., P. Ahlberg, And M. E. Eriksson. 2011. Complete record of Furongian polymerid trilobites and agnostoids of Scandinavia - a biostratigraphical scheme. Lethaia, 44:8-14.

Topper, T. P., C. B. Skovsted, G. A. Brock, AND J. R. PAterson. 2007. New bradoriids from the lower Cambrian Mernmerna Formation, South Australia: systematics, biostratigraphy and biogeography. Memoirs of the Association of Australasian Palaeontologists, 33:67-100.

Topper, T. P., C. B. Skovsted, G. A. Brock, And J. R. Paterson. 2011. The oldest bivalved arthropods from the early Cambrian of East Gondwana: Systematics, biostratigraphy and biogeography. Gondwana Research, 19:310-326.

Topper, T. P., L. E. Holmer, C. B. Skovsted, G. A. Brock, U. Balthasar, C. M. LARsson, S. PetTersson STOLK, AND D. A. T. HARPER. In press. The oldest brachiopods from the lower Cambrian of South Australia. Acta Palaeontologica Polonica. Doi: http://dx.doi.org/10.4202/app.2011.0146

Tullberg, S. A. 1880. Om Agnostus-arterna i de kambriska aflagringarne vid Andrarum. Sveriges Geologiska Undersökning, C 42:1-37.

WALLERIUS, I. D. 1894. Geologiska studier i Vestergötland. Geologiska Föreningens i Stockholm Förhandlingar, 16:298-306.

WALLERIUS, I. D. 1895. Undersökningar öfver zonen med Agnostus laevigatus i

Vestergötland, jämte en inledande öfversikt af Vestergötlands samtliga Paradoxideslager. Gleerupska Universitetsbokhandeln, Lund, 72 p.

WALLERIUS, I. D. 1930. Från Västergötlands mellankambrium. Geologiska Föreningens i Stockholm Förhandlingar, 52:47-62.

WALOsseK, D. 1993. The Upper Cambrian Rehbachiella and the phylogeny of Branchiopoda and Crsutacea. Fossils and Strata, 32:1-202. 
WeSTERGÅRD, A. H. 1922. Sveriges olenidskiffer. Sveriges Geologiska Undersökning, Ca 18:1-205.

WESTERGÅRD, A. H. 1944. Borrningar genom Skånes alunskiffer 1941-42. Sveriges Geologiska Undersökning, C 459:1-45.

Westergård, A. H. 1946. Agnostidea of the Middle Cambrian of Sweden. Sveriges Geologiska Undersökning, C 477:1-140.

WESTERGÅRD, A. H. 1947. Supplementary notes on the Upper Cambrian trilobites of Sweden. Sveriges Geologiska Undersökning, C 489:1-34.

WILLIAMS, A. J. 1970. Origin of laminar-shelled articulate brachiopods. Lethaia, 3:329-342.

Williams, A., S. J. Carlson, C. H. C. Brunton, L. E. Holmer and L. E. Popov. 1996. A Supra-ordinal classification of the Brachiopoda. Philosophical Transactions of the Royal Society, Biological Sciences, 355:1171-1193.

Williams, M., D. J. Siveter, M. Jose Salas, J. M. C. VAnnier, L. E. Popov, And M.

GHOBADI Pour. 2008. The earliest ostracods: the geological evidence.

Senckenbergiana lethaea, 88:11-21.

Williams M, J. VAnNiER, L. Corbari, And J.-C. MASSAbUaU. 2011. Oxygen as a Driver of early arthropod micro-benthos evolution. PLoS ONE 6(12): e28183. doi:10.1371/journal.pone.0028183.

WiMAN, C. 1905. Studien über das Nordbaltische Silurgebiet. Bulletin of the Geological Institution of the University of Uppsala 6:12-76.

WronA, R., 2004. Cambrian microfossils from glacial erratics of King George Island, Antarctica. Acta Palaeontologica Polonica, 49:13-56.

WronA, R., 2009. Early Cambrian bradoriidae and phophatocopidae arthropods from King George Island, West Antarctica; Biogeographic implications. Polish Polar Research, 30:347-377. 
ZHANG, W. T. 1953. Some Lower Cambrian trilobites from western Hubei. Acta Palaeontologica Sinica, 1:121-149.

ZHANG, X. G. 2007. Phosphatised Bradoriids (Arthropoda) from the Cambrian of China. Palaeontographica Abteilung A: Palaeozoologie-Stratigraphie, 281:93-173. 


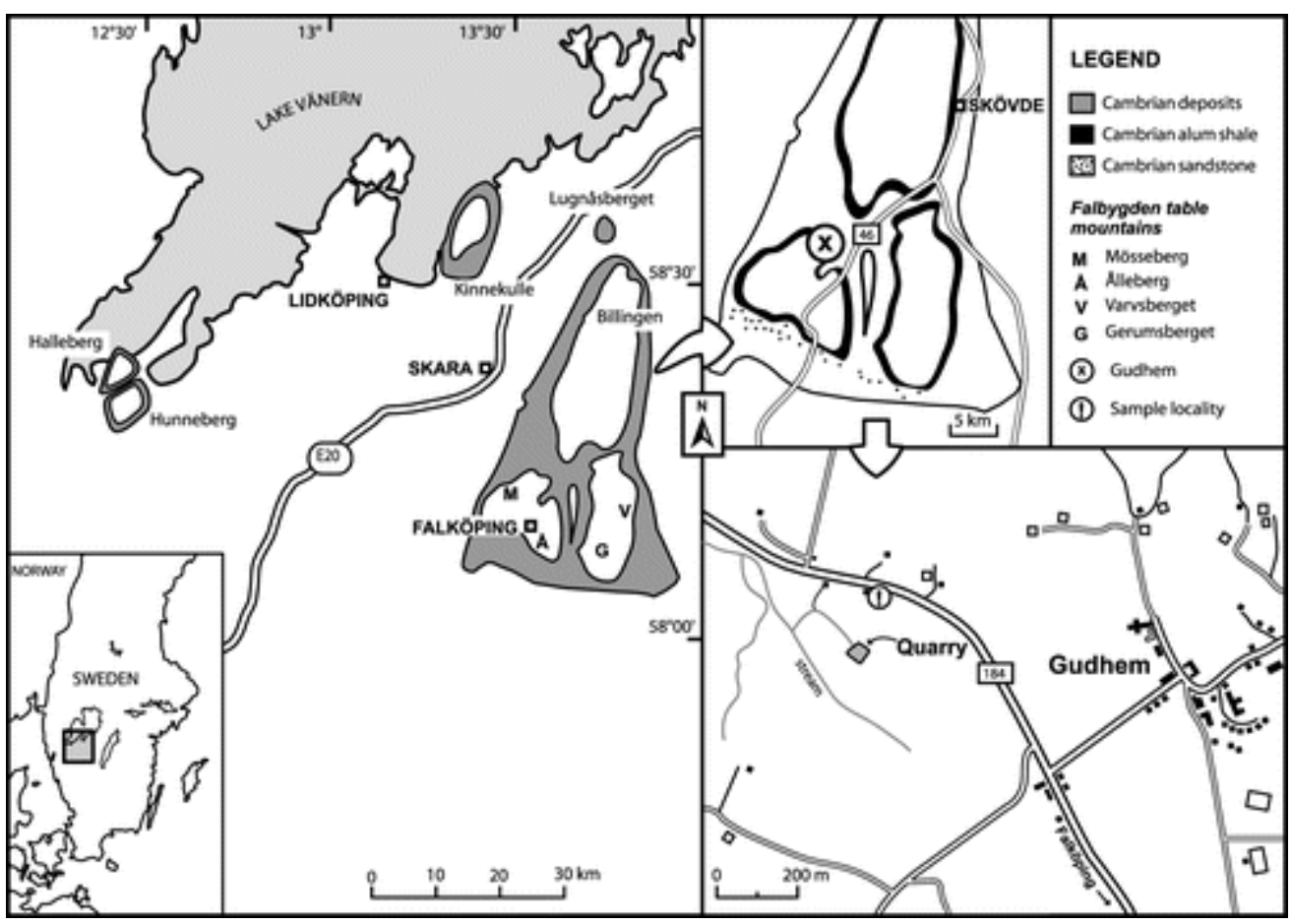

FIGURE 1- Locality map of Västergötland, south-central Sweden, showing Cambrian outcrop areas and the location of the sample locality just north of the Gudhem Quarry. (Figure revised from Axheimer et al., 2006, figure 3). 


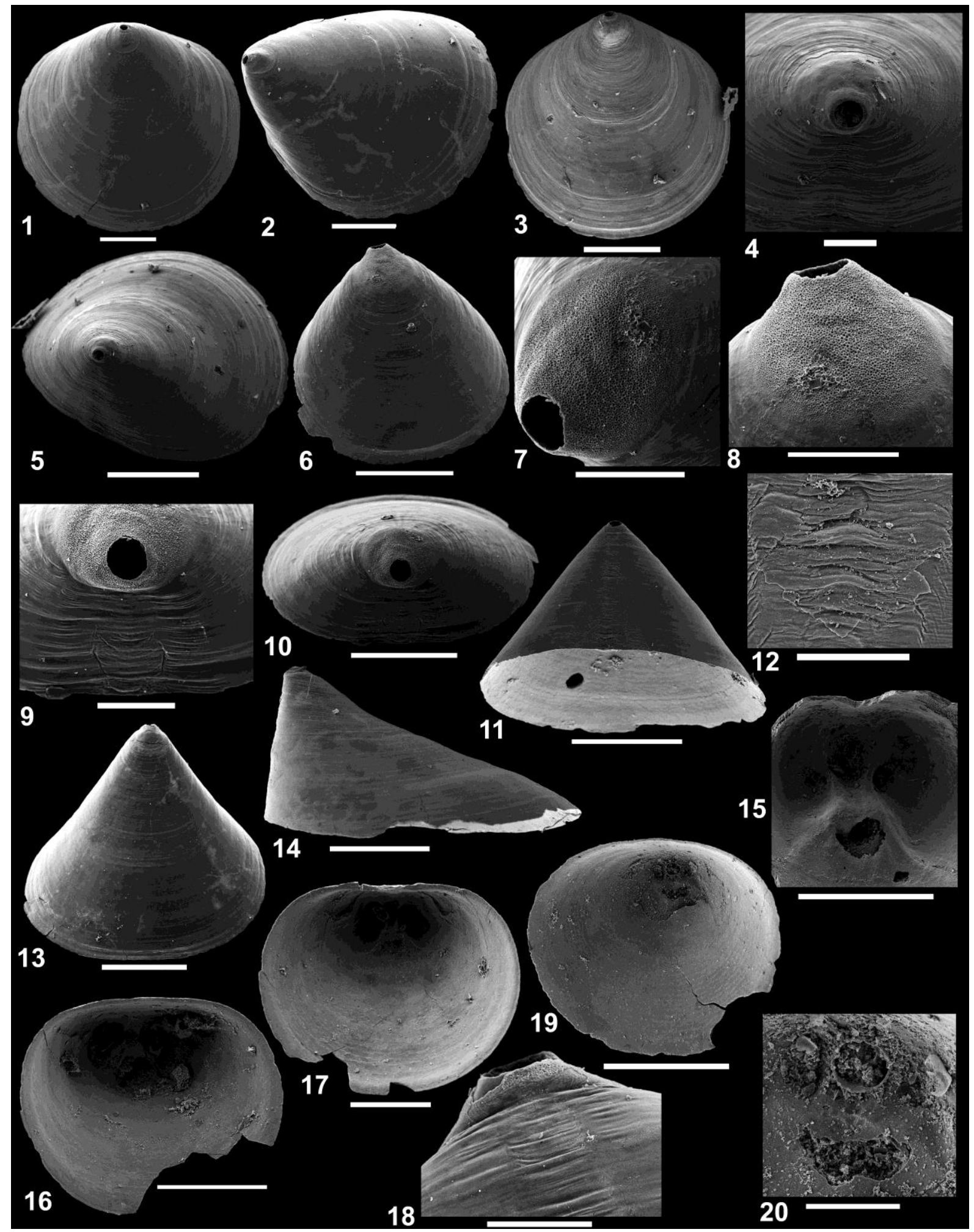

FIGURE 2-Treptotreta jucunda Henderson and MacKinnon, 1981. 1-2, LO11415t: 1, dorsal view of ventral valve; 2 , lateral view of ventral valve; $3-5$, LO11416t: 3 , dorsal view of ventral valve; 4 , close up of larval shell and pedicle foramen, scale bar $100 \mu \mathrm{m} ; 5$, lateral view of ventral valve; 6-10, LO11417t: 6 , anterior view of ventral valve, scale bar $300 \mu \mathrm{m} ; 7$, 
close up lateral view of larval shell, scale bar $100 \mu \mathrm{m} ; 8$, close up anterior view of larval shell, scale bar $100 \mu \mathrm{m} ; 9$, close up or pedicle foramen and intertrough, scale bar $100 \mu \mathrm{m} ; 10$, posterior view of ventral valve, scale bar $200 \mu \mathrm{m} ; 11-12$, LO11418t: 11, posterior view of ventral valve; 12 , close up of intertrough, scale bar $100 \mu \mathrm{m} ; 13$, anterior view of ventral valve, LO11419t; 14, lateral view of ventral valve, LO11420t; 15, close up of ventral valve interior showing apical process, LO11421t; 16, ventral valve interior, LO11422t; 17, ventral valve interior, LO11423t; 18, close up of intertrough and larval shell, scale bar $100 \mu \mathrm{m}$, LO11424t; 19-20, LO11425t: 19, ventral valve interior; 20, close up of pedicle tube, scale bar $100 \mu \mathrm{m}$.All scale bars $500 \mu \mathrm{m}$ unless otherwise stated. 


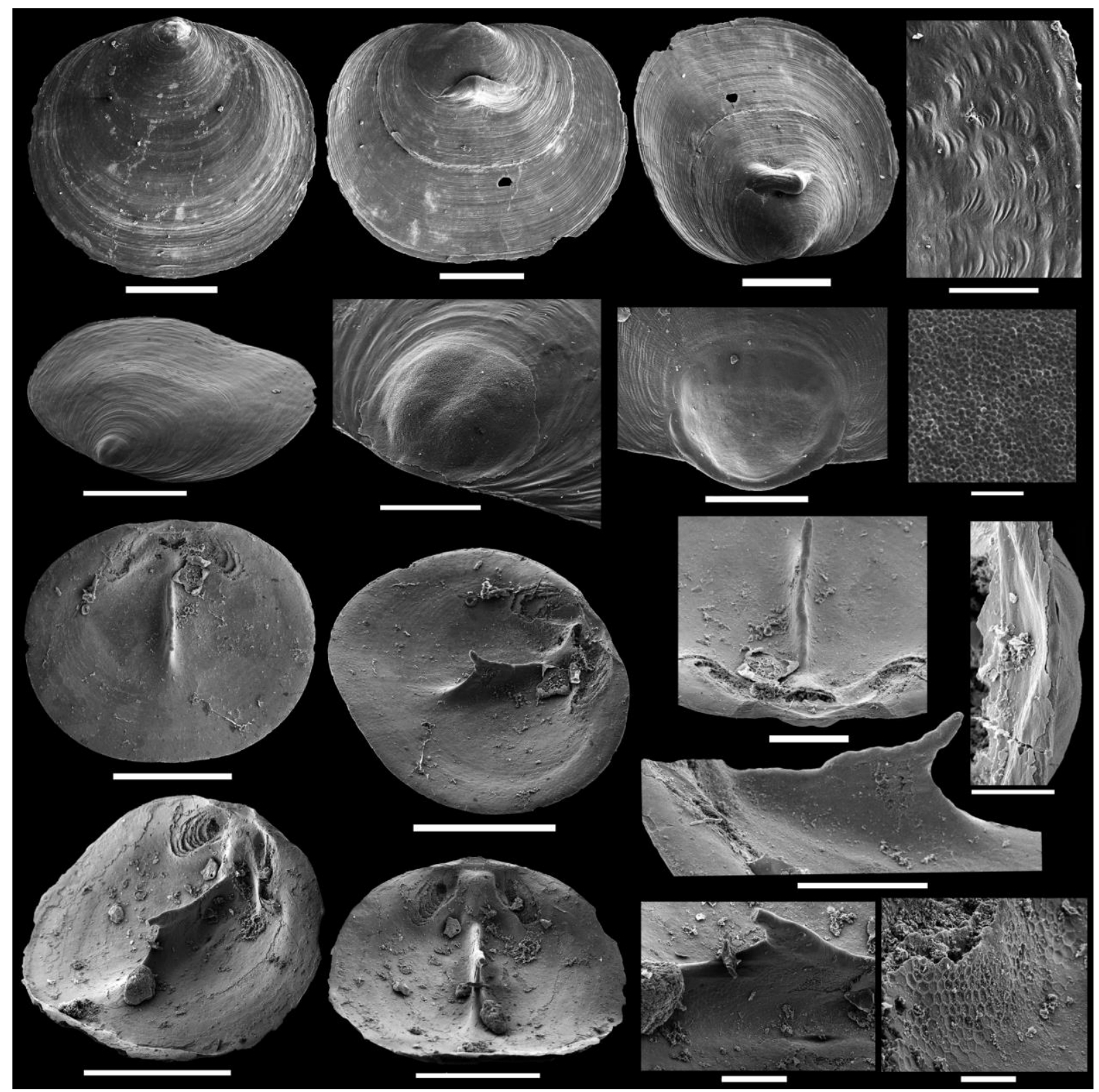

FIGURE 3-Treptotreta jucunda Henderson and MacKinnon, 1981. 1, dorsal view of dorsal valve, LO11426t; 2-3, LO11427t: 2, dorsal view of dorsal valve; 3, lateral view of dorsal valve; 4, close up of ornament on dorsal exterior, scale bar $100 \mu \mathrm{m}, \mathrm{LO} 11428 \mathrm{t} ; 5-6$,

LO11429t: 5, lateral posterior view of dorsal valve; 6 , close up of larval shell, scale bar 100 $\mu \mathrm{m} ; 7-8$, LO11430t: 7, close up of larval shell, scale bar $100 \mu \mathrm{m} ; 8$, close up of larval shell ornament, scale bar $10 \mu \mathrm{m}$; 9-13, LO11431t: 9, dorsal valve interior; 10, lateral view of dorsal valve interior; 11 , posterior view of dorsal valve pseudointerarea, scale bar $200 \mu \mathrm{m}$; 12, close up of larval shell and median groove, scale bar $50 \mu \mathrm{m} ; 13$, close up of triangular 
median septum, scale bar $200 \mu \mathrm{m} ; 14-16$, LO11432t: 14, lateral view of dorsal valve interior; 15 , anterior view of dorsal valve interior; 16 , close up of triangular median septum, scale bar $200 \mu \mathrm{m} ; 17$, close up of median septum displaying epithelial imprints, scale bar $50 \mu \mathrm{m}$, LO11433t . All scale bars $500 \mu \mathrm{m}$ unless otherwise stated.

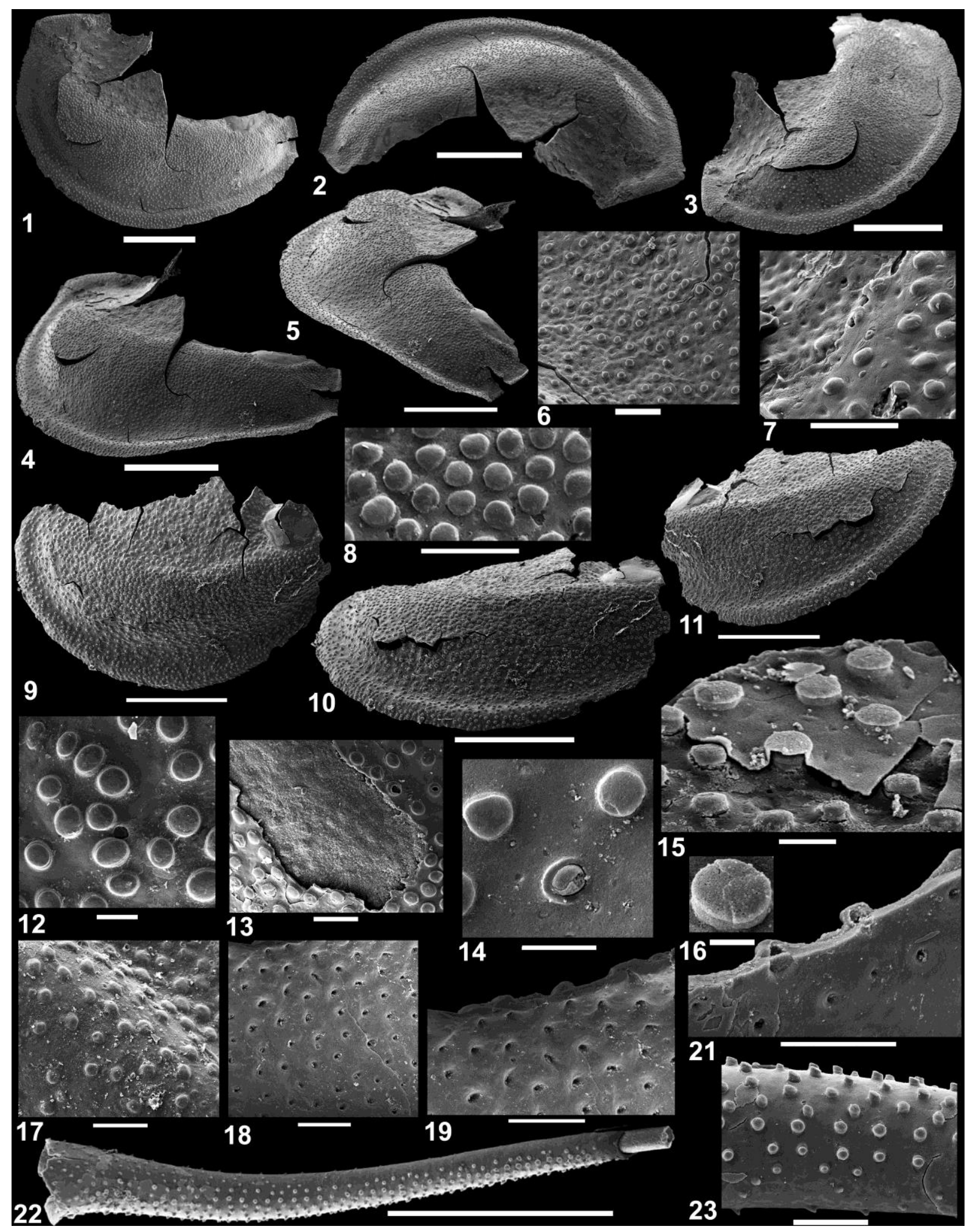


FIGURE 4-Mongolitubulus aspermachaera n. sp. 1-8, holotype, LO11434T: 1, lateral view of left valve; 2, dorsal view of left valve; 3 , oblique anterior view of left valve; 4 , ventral view of left valve; 5 , oblique posterior view of left valve; 6 , close up of ornament located in marginal furrow displaying wrinkling, scale bar $50 \mu \mathrm{m} ; 7$, close up of ornament displaying minute pores of the inner layer, scale bar $50 \mu \mathrm{m} ; 8$, close up of ornament, scale bar $50 \mu \mathrm{m} ; 9$ 11, LO11435T: 9, lateral view of valve; 10, ventral valve of valve; 11, oblique lateral view of valve; 12, close up of ornament, scale bar $20 \mu \mathrm{m}$, LO11436t; 13, close up of exterior displaying worn out layer and solid inner layer, scale bar $50 \mu \mathrm{m}, \mathrm{LO} 11437 \mathrm{t} ; 14-16$, LO11438t: 14, close up of raised, subcircular structures on valve surface, scale bar $20 \mu \mathrm{m}$; 15 , close up of valve surface showing worn outer later and immediate inner layer, scale bar $20 \mu \mathrm{m} ; 16$, close up of individual, subcircular structures on valve exterior, scale bar $10 \mu \mathrm{m}$; 17, close up of valve interior showing domed pads, scale bar $50 \mu \mathrm{m} ; 18-20$, LO11439t: 18, close up of valve interior, showing minute pores of the inner layer, scale bar $50 \mu \mathrm{m} ; 19$, close up of valve interior including broken margin, showing pores aligned with subcircular structures on the valve exterior, scale bar $50 \mu \mathrm{m} ; 20$, close up of broken valve margin, showing hollow, subcircular exterior structures, thin, solid inner layer, scale bar $50 \mu \mathrm{m} ; 21-$ 22, LO11440T: 21, lateral view of spine; 22 , close up of spine ornament, scale bar $50 \mu \mathrm{m}$. All scale bars $500 \mu \mathrm{m}$ unless otherwise stated. 


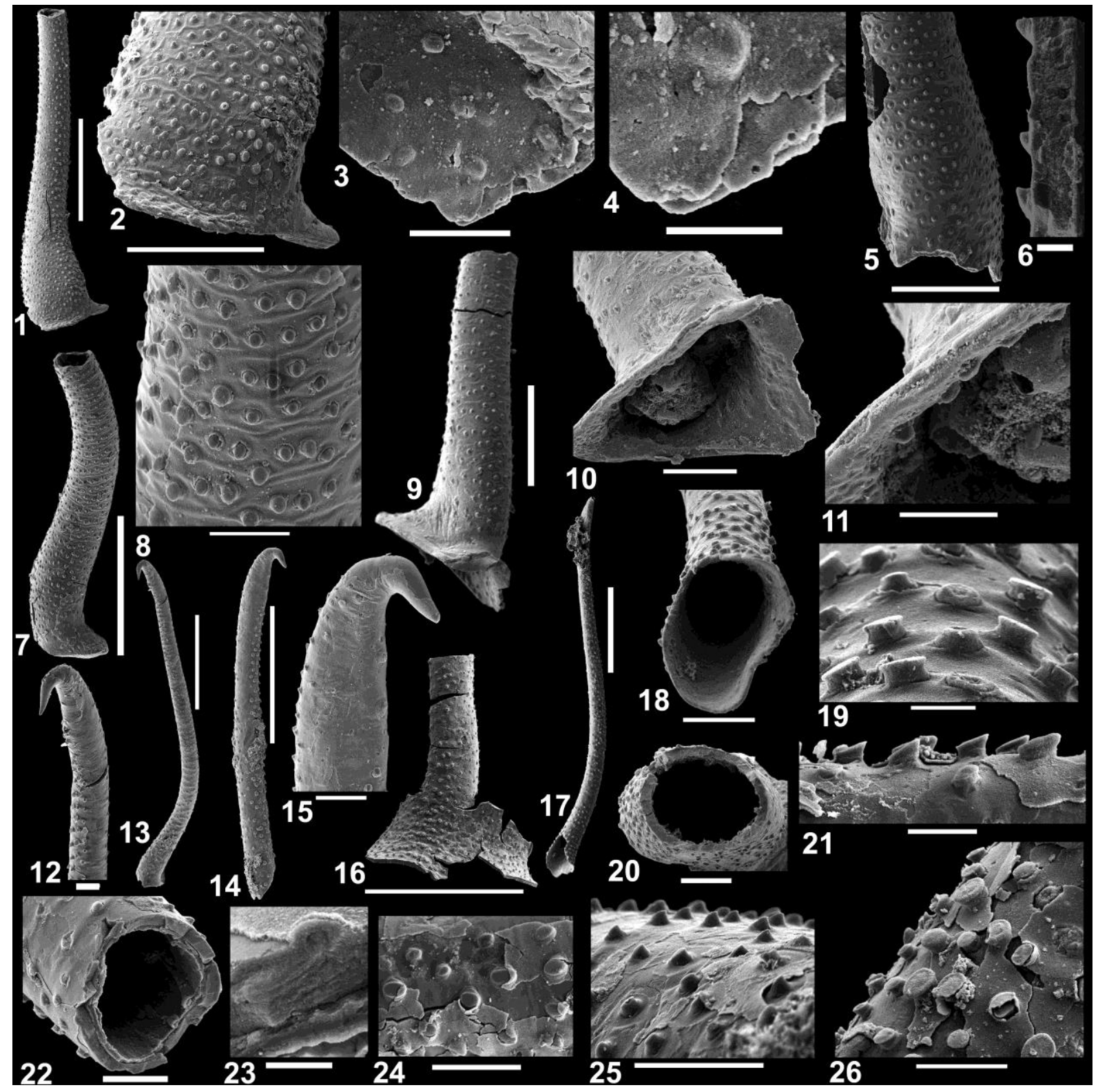

FIGURE 5-Mongolitubulus aspermachaera n. sp.1-4, LO11441T : 1, lateral view of spine,

scale bar $500 \mu \mathrm{m} ; 2$, close up of spine base, showing wrinkled surface, scale bar $200 \mu \mathrm{m} ; 3$,

close up of interior surface of spine, showing domed pads; 4 , close up interior of spine

showing minute pores on the inner layer, scale bar $20 \mu \mathrm{m} ; 5-6$, LO11442t: 5, lateral view of

spine base, scale bar $200 \mu \mathrm{m}$; 6 , close up of microstructure of broken margin of spine, scale

bar $10 \mu \mathrm{m}$; 7-8, LO11443t: 7, lateral view of spine, scale bar $500 \mu \mathrm{m} ; 8$, close up of spine

surface showing wrinkling on the surface; 9-11, LO11444t: 9, lateral view of spine, scale bar $200 \mu \mathrm{m} ; 10$, oblique view of spine base, scale bar $100 \mu \mathrm{m} ; 11$, close up of broken spine 
margin and interior, showing dome pads on the interior; 12-13, LO11445T: 12, close up of recurved spine tip; 13, lateral view of spine, scale bar $500 \mu \mathrm{m} ; 14-15$, LO11446T: 14, lateral view of spine, scale bar $500 \mu \mathrm{m} ; 15$, close of up recurved spine tip; 16 , lateral view of spine

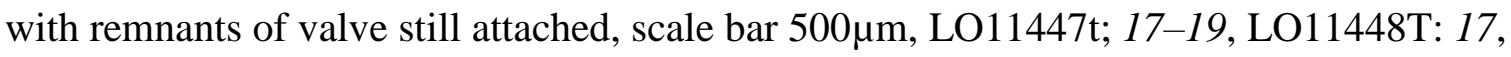
lateral view of spine, scale bar $500 \mu \mathrm{m} ; 18$, close up of spine base, showing cross section, scale bar $100 \mu \mathrm{m} ; 19$, close up of ornament on spine surface, scale bar $20 \mu \mathrm{m} ; 20$, cross section of broken spine, scale bar $100 \mu \mathrm{m}, \mathrm{LO} 11449 \mathrm{t}$; 21, close up of spine surface, scale bar $20 \mu \mathrm{m}$, LO11450t;22-23, LO11451t: 22, cross section of broken spine; 23, close up of microstructure, scale bar $10 \mu \mathrm{m} ; 24$, close up of spine surface, LO11452t; 25, oblique view of spine surface, LO11453t; 26, oblique close up of spine surface, showing worn outer layer, LO11454t;. All scale bars $50 \mu \mathrm{m}$ unless otherwise stated. 


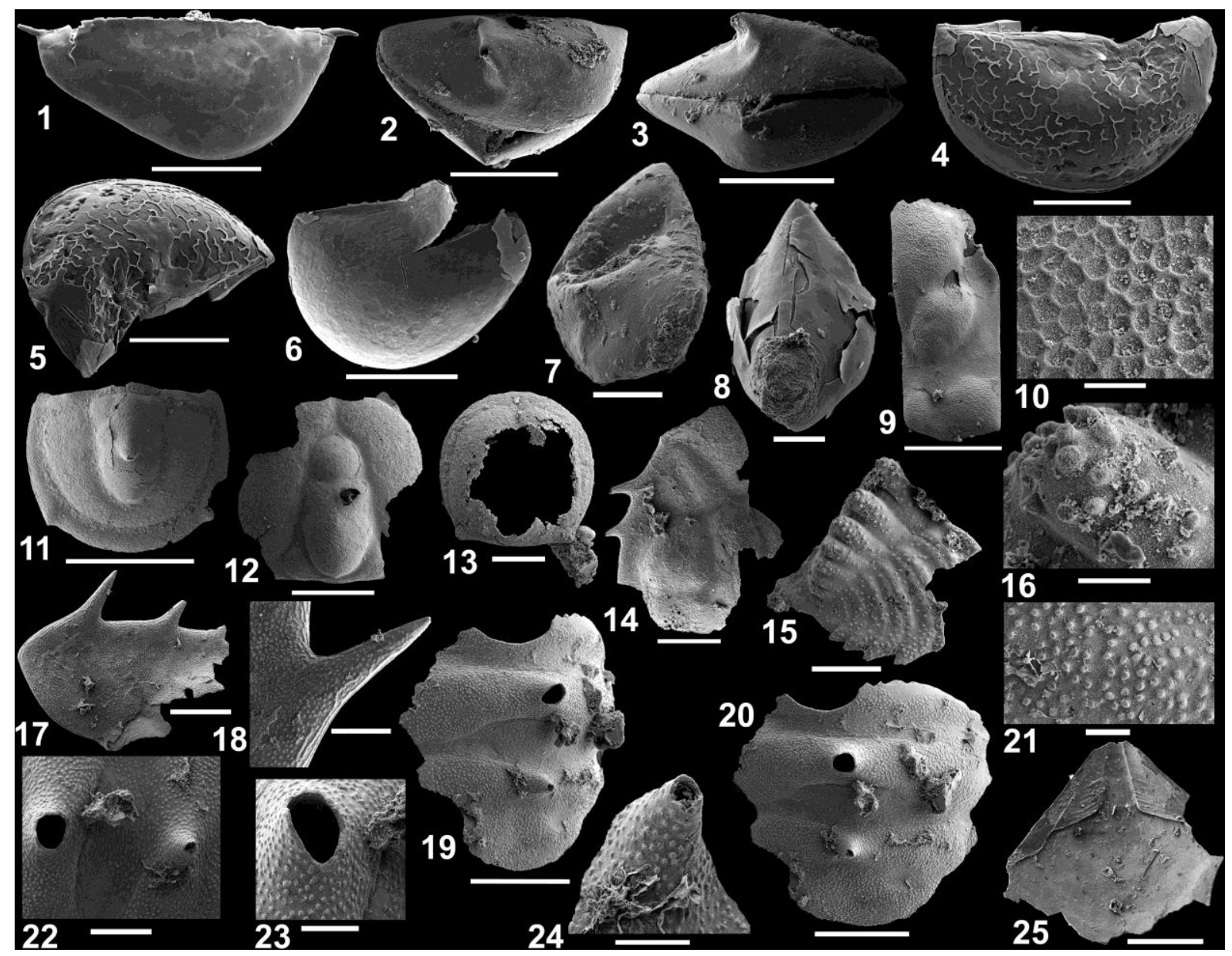

FIGURE 6- Remaining elements of the Västergötland faunal assemblage, including phosphatocopids, trilobites, agnostoids, and a brachiopod. 1-8, Phosphatocopids; 1 , Hesslandona sp., LO11455t; 2-3, Vestrogothia longispinosa Kozur, 1974, LO11456t; 4-5, indeterminate phosphatocopid, LO11457t; 6, indeterminate phosphatocopid, LO11458t; 7, indeterminate phosphatocopid, scale bar $100 \mu \mathrm{m}$, LO11459t; 8, indeterminate phosphatocopid, scale bar $100 \mu \mathrm{m}$, LO11460t; 9-24, Agnostoids and trilobites; 9-13, Agnostus sp.; 9-10, LO11461t ; 9, dorsal view of incomplete first thoracic segment, scale bar $500 \mu \mathrm{m} ; 10$, close up of surface, scale bar $40 \mu \mathrm{m} ; 11$, pygidium, scale bar $500 \mu \mathrm{m}$,

LO11462t; 12, incomplete cephalon, scale bar $500 \mu \mathrm{m}$, LO11463t; 13, incomplete cephalon, LO11464t; 14, Parabolina cf. brevispina Westergård, 1922, dorsal view of pygidium, scale bar $500 \mu \mathrm{m}$ LO11465t; 15-16, unidentified trilobite pygidium, LO11466t; 15, oblique posterodorsal view; 16 , close up of surface, scale bar $40 \mu \mathrm{m} ; 17-24$, Parabolina $\mathrm{cf}$. 
brevispina Westergård, 1922; 17-18, incomplete pygidium, scale bar $500 \mu \mathrm{m}$ for 17 , LO11467t; 18, close up of outer marginal spine; 19-24, axial region of two articulated segments, LO11468t; 19, oblique dorsal view, scale bar $500 \mu \mathrm{m} ; 20$, dorsal view; 21, close up of surface, scale bar $50 \mu \mathrm{m} ; 22$, close up of broken axial spines; 23 , cross section and base of anterior axial spine, scale bar $100 \mu \mathrm{m} ; 24$, close up of posterior axial spine, scale bar 100 $\mu \mathrm{m} ; 25$, ventral valve fragment of a lingulid brachiopod, LO11469t, scale bar $500 \mu \mathrm{m}$. All scale bars $200 \mu \mathrm{m}$ unless otherwise stated. 